\title{
台湾新生代层序：反映南海张裂，层序和 古海洋变化机制
}

黄奇瑜 ${ }^{(2)}$, 间义 ${ }^{(1)}$, 赵泉鸿 ${ }^{(3)}$, 刘平妹 ${ }^{(4)}$, 林彦均 ${ }^{(2)}$, 林秋婷 ${ }^{(1)}$, 谢凯旋 ${ }^{(5)}$

(1) 中国科学院广州地球化学研究所, 边缘海地质重点实验室, 广州 510640;

(2) 成功大学地球科学系, 台南 701 ;

(3) 同济大学海洋地质国家重点实验室, 上海 200092;

(4) 台湾大学地质科学系, 台北 106 ;

(5) 地质调查所, 新北 235

E-mail: Huangcy@mail.ncku.edu.tw

2011-11-23 收稿, 2012-03-08 接受

国家自然科学基金重大研究计划(91128211)、中国科学院知识创新工程重要方向项目(KZCX2-EW-101)和国家自然科学基金(41176041)资助

摘要 ODP 1148 站位记录南海 $32 \mathrm{Ma}$ 以来深海层序、沉积、古气候和古海洋变化记录. 由于 板块聚合，台湾新生代造山带出露原来沉积在南海北坡浅海的层序，提供南海浅海地质记录， 以进行和 ODP1148 深海记录比较. 地震反射及微体古生物研究表明台湾造山带古近系是在断 陷盆地内沉积的同张裂层序, 并为晚渐新世-新近纪后张裂层序不整合覆盖。两者间破裂不整 合面缺失晚始新世-早渐新世的地层记录, 可对比珠江口盆地 $\mathrm{T}_{7}$ 不整合面, 推论南海海洋地壳 开始形成时间可能在33 39 Ma 间. 西部麓山带并未发现如 ODP 1148 深海岩心于渐新世/中新 世界面附近记录的地层缺失或沉积崩滑现象，显示此沉积事件可能仅影响南海的深海区，而不

\section{关键词}

台湾 新生代层序

南海

地质记录

大洋钻探

1148 站位 及浅海陆棚区。南海在中中新世发生的古海洋重组，在台湾浅海区层序则显示在沉积及化石组 合的改变. 在沉积方面自中中新世上陆坡相沉积改变为晚中新世海滨-沼泽相沉积. 在化石组 合方面底栖有孔虫丰度自 $15 \mathrm{Ma}$ 迅速减少，台湾原生特征种底栖有孔虫在 14 13 Ma 绝灭， 12.9 10.2 Ma 间完全缺乏海相化石, 一直到 $10.2 \mathrm{Ma}$ 出现现代黑潮陆棚生物组合. 此化石组合 改变推论可能因 12 8 Ma 时澳大利亚大陆与印度尼西亚火山岛弧俯冲-碰撞, 关闭了太平洋-印 度洋穿越流路径, 强化了北太平洋西边界流。自中中新世南海海洋岩石圈向东俯冲于菲律宾海 板块之下, 形成增生楔与火山岛弧, 台湾造山带增生楔-岛弧的造山演化直接控制南海与西太 平洋水团的交换及南海半封闭下古海洋底栖有孔虫氧碳同位素值的变化记录, 尤其在下列构造 演化事件特别明显: 15 8 Ma 时增生楔形成及火山岛弧喷发活动; $6.5 \mathrm{Ma}$ 时增生楔开始出露; 北 吕宋火山岛弧 3 个火山岛间闸口于 3.5, 1, 及 $0 \mathrm{Ma}$ 关闭。这些事件发生时南海深海底栖有孔 虫碳同位素值呈明显负偏移。

南海为西太平洋低纬度区最大的边缘海之一, 具年轻海洋地壳 (晚渐新世-中中新世) ${ }^{[1]}$, 同时具备被 动式及活跃式大陆边缘，和沉积速率快等特征. 南海 北坡为被动大陆边缘，在中生代末期-新生代早期于
华南欧亚大陆地壳上因正断层断陷发生, 形成珠江 口盆地 ${ }^{[2]}$, 断陷盆地古近纪同张裂层序沉积以湖相叶 岩为主，并为新近纪后张裂层序不整合覆盖. 在形成 古近纪断陷盆地后，被动大陆边缘因大陆地壳持续

英文版见: Huang C Y, Yen Y, Zhao Q H, et al. Cenozoic stratigraphy of Taiwan: Looking into rifting, stratigraphy and paleoceanography of South China Sea. Chin Sci Bull, 2012, 57, doi: 10.1007/s11434-012-5349-y 
拉张减薄, 最后基性岩浆冒出, 形成南海海洋地壳及 慢速张裂中洋脊，于南海中央海盆产生东-西向排列 的中洋脊及 $\mathrm{C}_{11} \sim \mathrm{C}_{5 \mathrm{~d}}$ 古地磁异常条带 ${ }^{[3]}$. 最后在中新 世中期南海海洋地壳不但停止扩张, 且岩石圈沿着 马尼拉海沟向东俯冲于菲律宾海板块之下 ${ }^{[4]}$; 俯冲的 南海海洋地壳随之部分融溶产生北吕宋火山岛弧喷 发于花东海盆之上(图 1), 南海面积遂逐渐削减缩小, 终于形成今日的形貌.

过去对南海地质大量的研究, 大多藉由间接的 地球物理方法及昂贵的钻探去了解现代海床以下的 南海地质，几乎完全缺乏在与南海北坡地质息息相 关的陆地造山带, 直接进行露头观察, 方便采样及多 学科交叉分析, 以进行南海地质最基本的几项科学 问题研究: 南海海洋地壳开始张裂时间, 形成南海今 日半封闭的时间及机制, 及南海由张裂到半封闭过 程中因海陆格局改变而发生的沉积、层序、沉积物来 源、古气候和古海洋变化事件及机制.

台湾岛为中中新世南海海洋岩石圈开始向东俯 冲于菲律宾海板块之下形成的增生楔 ${ }^{[5,6]}$ (图 1). 在俯 冲的过程中, 原来在南海北坡被动大陆边缘沉积的 层序被铲刮变形为增生楔, 再经 $6.5 \mathrm{Ma}$ 以来的台湾 地区斜向弧陆碰撞, 最后出露形成台湾岛 ${ }^{[7]}$. 因此, 台湾岛实际上就是 “出露的南海”, 提供为研究南海 浅海区地质的窗口. 台湾岛位处亚洲大陆东南, 北连 东海, 西为台湾海峡, 西南接南海, 南为吕宋海峡, 东临花东海盆(图 1). 台湾岛南北长 $370 \mathrm{~km}$, 东西宽 最大 $140 \mathrm{~km}$, 为中新世中期到现代(大约 $16 \mathrm{Ma}$ 以来) 正活跃的造山带, 属于西太平洋活跃地震-火山活动 带上的一段. 台湾岛呈南北向, 主构造线呈北北东方 向, 在台湾东北部略呈东北方向, 中南部则呈南北方 向. 台湾西南部及东北部海域分别存在着俯冲方向 相异的马尼拉海沟及琉球海沟(图 1). 欧亚板块以南 海海洋岩石圈为前导, 沿马尼拉海沟向东俯冲于菲 律宾海洋板块之下; 菲律宾海洋板块又沿琉球海沟 向北俯冲于张裂的欧亚大陆之下. 前者建设性地控 制着台湾岛的南-北向造山演化，而后者则伴演着将 台湾岛造山带崩解破坏性的地质角色. 依地形单元, 台湾岛由西向东可分成为海岸平原、西部麓山带、雪 山山脉、中央山脉及海岸山脉(图 1). 依地质背景, 台 湾岛由西向东可分成 3 个南-北向主要地质构造带: 在被动大陆边缘上变形发生的祽皱-逆冲带(包括海 岸平原、西部麓山带、雪山山脉), 增生楔(恒春半岛一
中央山脉)及弧前盆地-火山岛弧(海岸山脉; 图 1).

台湾岛新生代地质历史经历 3 个主要构造事件:

(1) 在古生代(?)-中生代大陆前张裂基盘上发生古新 世-始新世断陷活动, 产生地堑-半地堑张裂盆地 ${ }^{[8]}$; (2) 中新世中期南海海洋岩石圈向东俯冲于菲律宾 海板块之下, 产生活跃大陆边缘体系(包括恒春海脊 增生楔，北吕宋海槽弧前盆地及北吕宋火山岛弧 ${ }^{[6,9]}$ ); (3) 中新世最晚期( $<6.5 \mathrm{Ma}$ )以来北吕宋火山岛弧与 欧亚大陆边缘发生斜向弧陆碰撞构造 ${ }^{[7]}$ 形成今日台 湾岛.

梨山-荖浓断层以东的中央山脉-恒春半岛为增 生楔，由(a) 中央山脉东翼的古生代晚期(?)-中生代 大理岩、片岩、片麻岩(统称大南澳群), (b) 始新世浅 海相变质砂岩-板岩, 及(c) 中央山脉西翼-恒春半岛 的中新世深海相板岩-浊流层组成(图 1,2). 在 $6.5 \mathrm{Ma}$ 弧陆碰撞构造发生以前, 梨山-荖浓断层以西为被动 式亚洲大陆边缘，由中生代基盘(只在北港基盘高区 及台湾海峡井下钻遇)、古近纪同张裂层序、晚渐新 世-更新世后张裂层序组成(图 2). 被动式亚洲大陆边 缘层序全为浅海相-海陆过渡相沉积, 在中新世最晚 期开始发生的斜向弧陆碰撞构造中，才被变形为褶 坡-逆冲带, 并且位于越西位置的造山带出露的岩层 越年轻(由东向西，雪山山脉：始新世(古新世?)-早中 新世; 西部麓山带: 晚渐新世-更新世; 海岸平原: 晚更 新世-全新世)。海岸山脉由中新世-上新世火山岛弧及 上新世-更新世弧前盆地及弧上盆地浊流层组成(图 2).

南海海洋地壳开始张裂的时间及形成今日半封 闭深海环流体系的机制, 为南海地质研究最关键的 两个基本科学问题. 另一方面, 南海由张裂到半封闭 过程中, 由于海陆格局的改变及南海周围边缘海复 杂的板块构造，也可能影响了沉积物源区及古气候 和古海洋环境的改变. 本文的目的为兼顾评述也提 出新研究成果讨论台湾造山带中第三纪沉积层序特 征, 化石组合记录及构造演化, 并与南海 ODP 1148 深海岩心记录南海 $32 \mathrm{Ma}$ 以来层序, 沉积和古气候古海洋事件相比较，以了解南海由张裂到半封闭过 程 ${ }^{[10 ~ 15]}$ 在浅海区的响应. 尤其聚焦于：(1) 了解南海 张裂过程中产生破裂不整合面的时间，藉以推论南 海海洋地壳形成的时间; (2) 渐新世/中新世界面附近 沉积层序是否缺失及滑塌现象发生, 用以推论古地 磁异常条带 $\mathrm{C}_{7}$ 时中洋脊跳迁构造对沉积层序的影响 范围; (3) 南海北坡浅海区古海洋及化石内容的变化, 


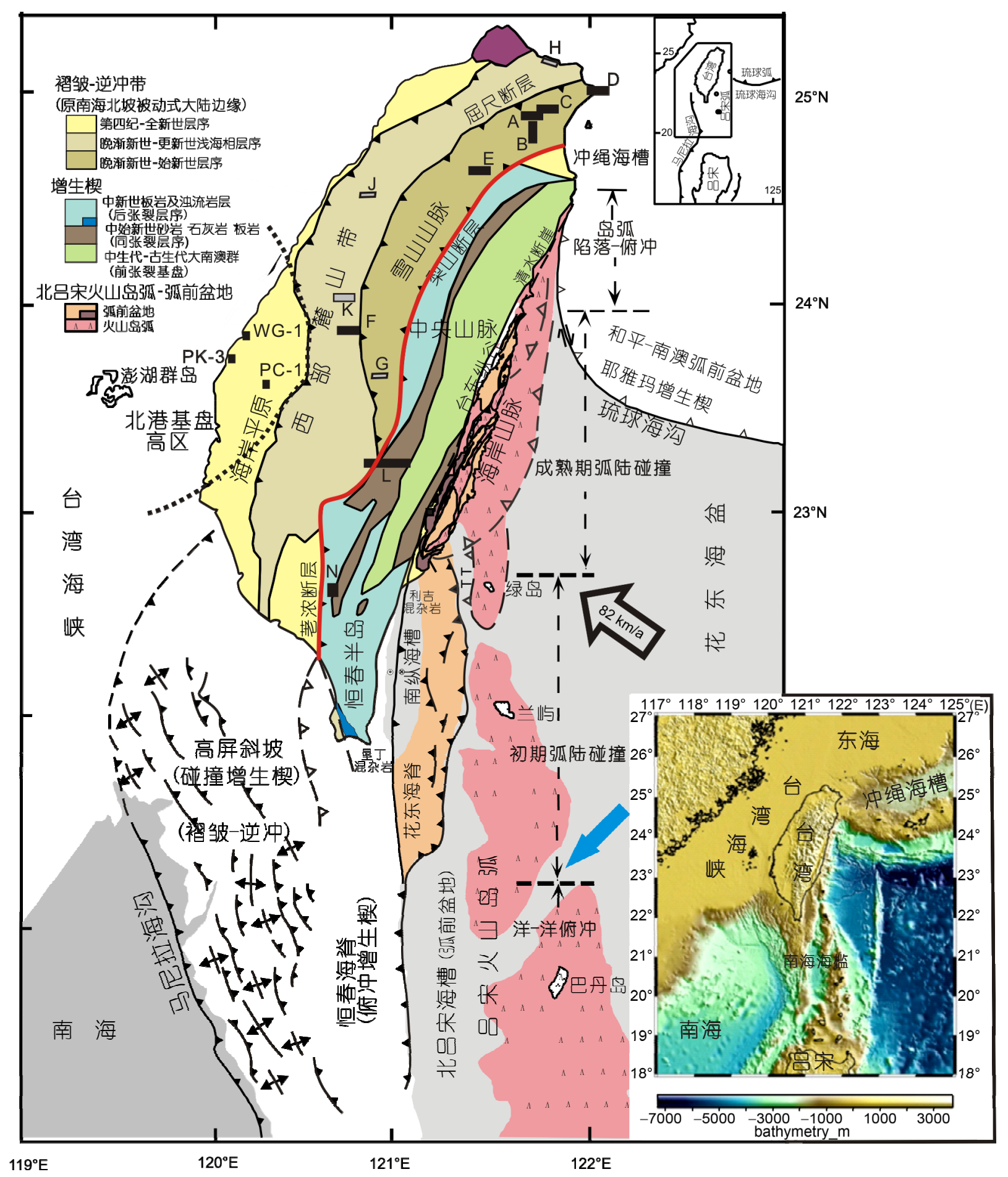

图 1 台湾附近大地构造及研究剖面位置

在空间上 4 个构造步骤正在台湾造山带及周围海域进行中, 由南向北: 洋-洋俯冲, 初期弧陆碰撞, 成熟期弧陆碰撞和岛弧俯冲/下陷; 在时间 上这 4 个构造步骤也就是台湾造山带在 $16 \sim 6.5,6.5 \sim 1,<1$ 及 $0 \mathrm{Ma}$ 进行的构造演化过程 ${ }^{[5-7]}$. 研究剖面包括: $\mathrm{A}$, 北势溪剖面; B, 南势溪剖面; C, 北宜公路剖面; D, 龙洞岬剖面; E, 北部横贯公路剖面; F, 国姓北港溪剖面; G, 郡坑溪剖面; H, 基隆外木山剖面; J, 苗栗出磺坑剖面; K, 南投 粗坑背斜剖面; L, 南部横贯公路剖面; N, 南大武山; TT, 台东海槽; WG-1, PC-1, PK-3 为海岸平原钻探井位. 黑色箭头为菲律宾海板块相对于 欧亚大陆运动速度; 蓝色箭头为今日太平洋深层水团流经兰屿与巴丹火山岛间闸口巴士海峡进人南海的主要通道 


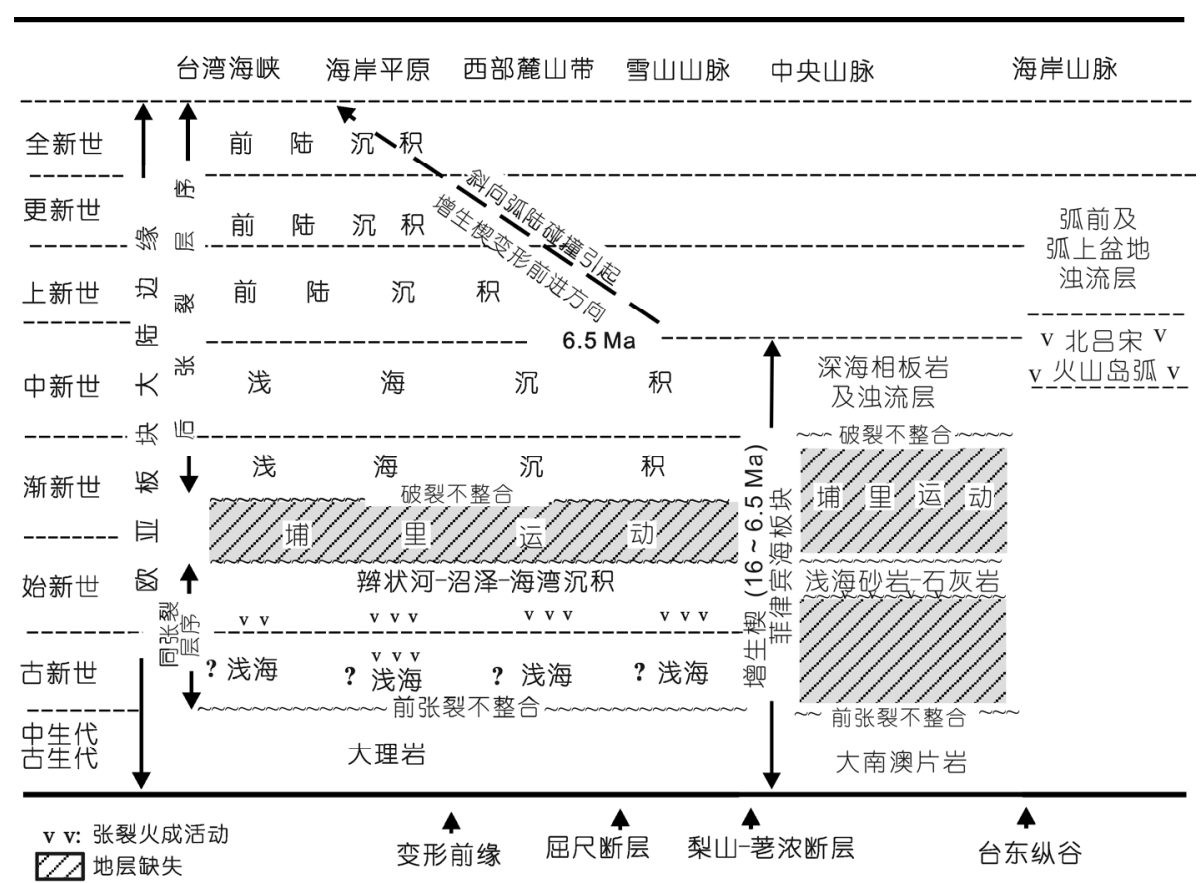

图 2 台湾构造地层序(修改自文献[6])

梨山-荖浓断层以西为 $6.5 \mathrm{Ma}$ 弧陆碰撞前的被动大陆边缘, 梨山-荖浓断层以东为活动大陆边缘, 包括中央山脉增生楔及海岸山脉火山岛弧、弧 上盆地及弧前盆地

以响应南海深海盆中新世中期以来古海洋重组事件; (4) 台湾构造演化引起南海半封闭的机制与表现在 南海深海盆古海洋事件记录的探讨.

任何被动大陆边缘张裂产生新海洋地壳的过程 中 (如大西洋、澳大利亚大陆北缘、南海)总存在 3 套 层序，由下而上为前张裂层序(张裂基盘)、同张裂层 序(断陷盆地)及后张裂层序. 此 3 套层序间分别以前 张裂不整合面及破裂不整合面分界. 另外, 在断陷盆 地同张裂层序中常伴随有因大陆地壳减薄而产生的 基性火成活动. 因此, 沉积层序中含破裂不整合面及 同张裂层序中存在基性火成喷发岩，为在造山带中 认识南海北坡古近纪断陷盆地同张裂层序的两个基 础特征. 下面的讨论是汇总已发表文献及正在进行 研究中有关台湾地区古近纪张裂盆地层序的成果, 讨论内容从未造山且尚保留原来沉积盆地形貌的台 湾海峡及台湾岛西部海岸平原开始, 向东经西部麓 山带-雪山山脉到中央山脉, 以探讨台湾地区出露南 海北坡层序中的破裂不整合面时间. 台湾地区破裂 不整合面时间确定以后，继而扩展到与南海北坡珠 江口盆地破裂不整合面时间记录的比较, 以推测南 海海洋地壳开始形成的可能地质时间.

\section{1 台湾新生代破裂不整合面的存在推论南 海张裂开始产生海洋地壳的时间}

\section{1 台湾海峡及西部海岸平原}

石油工业界在台湾海峡及台湾岛西部海岸以反 射地震方法发现有数个典型以正断层为边界的古近 纪断陷张裂盆地(如澎湖盆地) ${ }^{[8,16 ~ 18]}$. 澎湖盆地的钻 探证实在古近纪同张裂层序含中始新世(钙质超微化 石 NP15 16 带)为主的叶岩, 上覆厚层火山喷发岩, 古近纪同张裂层序为中新世后张裂层序不整合覆盖 (图 3). 在地形构造高区，如北港基盘高区(南海北坡 中央构造东沙隆起的延伸; 图 1), 发现下中新统不整 合覆盖于古新世(如王功一号井 ${ }^{[18]}$; 图 1, WG-1) 或 中始新世火山喷发岩及砂泥岩(图 1, PC-1; K-Ar 定年 为 $\left.44.1 \pm 2.2 \mathrm{Ma}^{[17]}\right)$ 同张裂层序之上. 甚至于在构造最 高区(图 1, PK-3), 早中新世后张裂层序更直接覆盖 在中生代早白严纪前张裂基盘之上 ${ }^{[8]}$.

\section{2 西部麓山带}

过去台湾地质学界普遍地认为西部麓山带出露 最老的地层为晚渐新世五指山层(图4). 五指山层主 


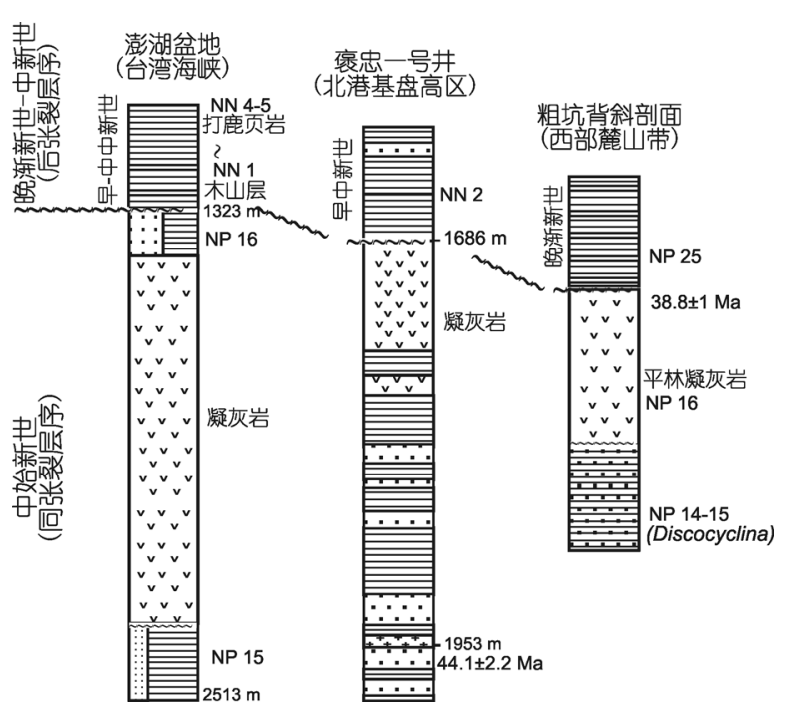

图 3 台湾海峡澎湖盆地 ${ }^{[16]}$ 与台湾岛海岸平原北港基盘高区 上 PC-1 钻井 ${ }^{[17]}$ 和西部麓山带粗坑背斜层序地层 ${ }^{[19 \sim 21]}$ 对比 说明始新世同张裂层序为晚渐新世-新近纪后张裂层序不整合覆盖

要出露在台湾北部的西部麓山带基隆外木山剖面(图 $1, \mathrm{H})$, 五指山层的下部为嵌脚逆冲断层所截, 故不 知五指山层以下还有什么地层, 更不知五指山层以 下地层属予何种盆地性质. 最近的研究 ${ }^{[19 \sim 21]}$ 则表明 在台湾中部南投县境西部麓山带粗坑背斜剖面(图 1, $\mathrm{K}$ ), 证实在五指山层(只出露其最上部)之下不整合存 在始新世断陷盆地 (命名为南投盆地 ${ }^{[19 ~ 21]}$ )同张裂层
序, 显示西部麓山带与台湾海峡澎湖盆地及南海北 坡珠江口盆地一样具相同盆地特征.

南投县境西部麓山带粗坑背斜轴部(图 $1, K$ ) 出露 层序原被认为是早中新世“粗坑层”(图 5 左) ${ }^{[22,23]}$, 后 经详细的微体古生物研究, 发现背斜轴部其实含 3 个 独立岩性地层单位, 由上而下为渐新世最晚期五指 山层，中始新世平林凝灰岩及中寮层(图 5)。五指山 层之上尚有早中新世木山层、大寮层及以上地层. 大 寮层含 N5 带浮游有孔虫化石组合及底栖有孔虫 Gaudryina pseudohayasakai 带及 Gaudryina kokuseiensis 带化石 ${ }^{[20,24]}$ ，此层序与在国姓地区北港溪剖面

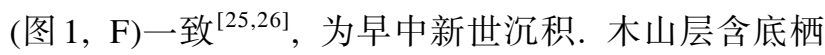
有孔虫 Gaudryina hayasakai 带化石组合; 五指山层 含典型晚渐新世 Globigerina ciperoensis, G. angulisuturalis (N2 N4 带)等浮游有孔虫化石, 底栖有孔 虫 Gaudryina hayasakai 带化石组合和钙质超微化石 NP 25 带组合 ${ }^{[19,20]}$. 但台湾中部粗坑背斜的五指山层 (<200 m 厚; NP25 带)只相当于台湾北部标准剖面五 指山层 (836 m 厚; NP 24 25 带) ${ }^{[26]}$ 的最上部, 因为 粗坑背斜出露的五指山层不整合覆盖于平林凝灰岩 之上. 平林凝灰岩经锆石 U-Pb (LA-ICP-MS) 测年为 $38.8 \pm 1 \mathrm{Ma}$ (晚期中始新世), 并含少量 NP 16 带钙质 超微化石 ${ }^{[20]}$. 平林凝灰岩假整合在中寮层之上(图 5). 中寮层含中始新世 Discocyclina dispansa ex. inter.

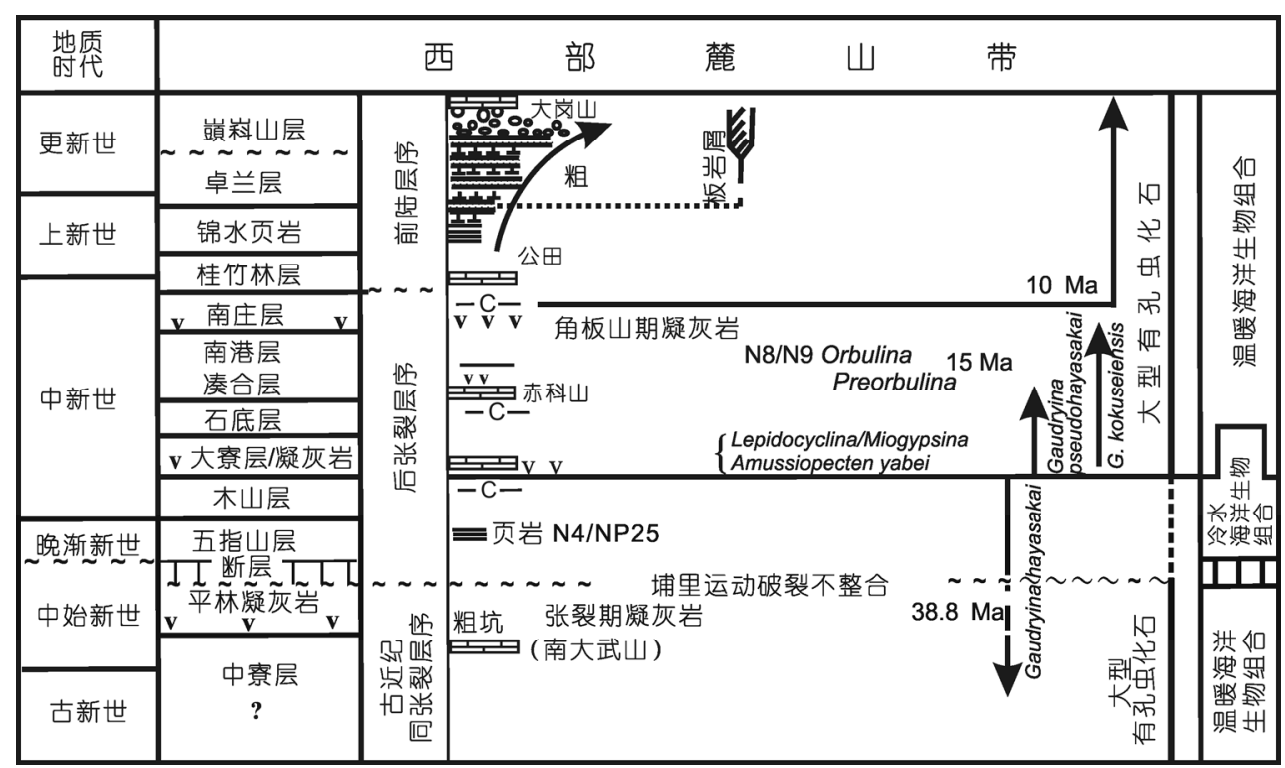

图 4 台湾西部麓山带北段新生代层序及主要化石内容 $\mathrm{V}$, 凝灰岩 


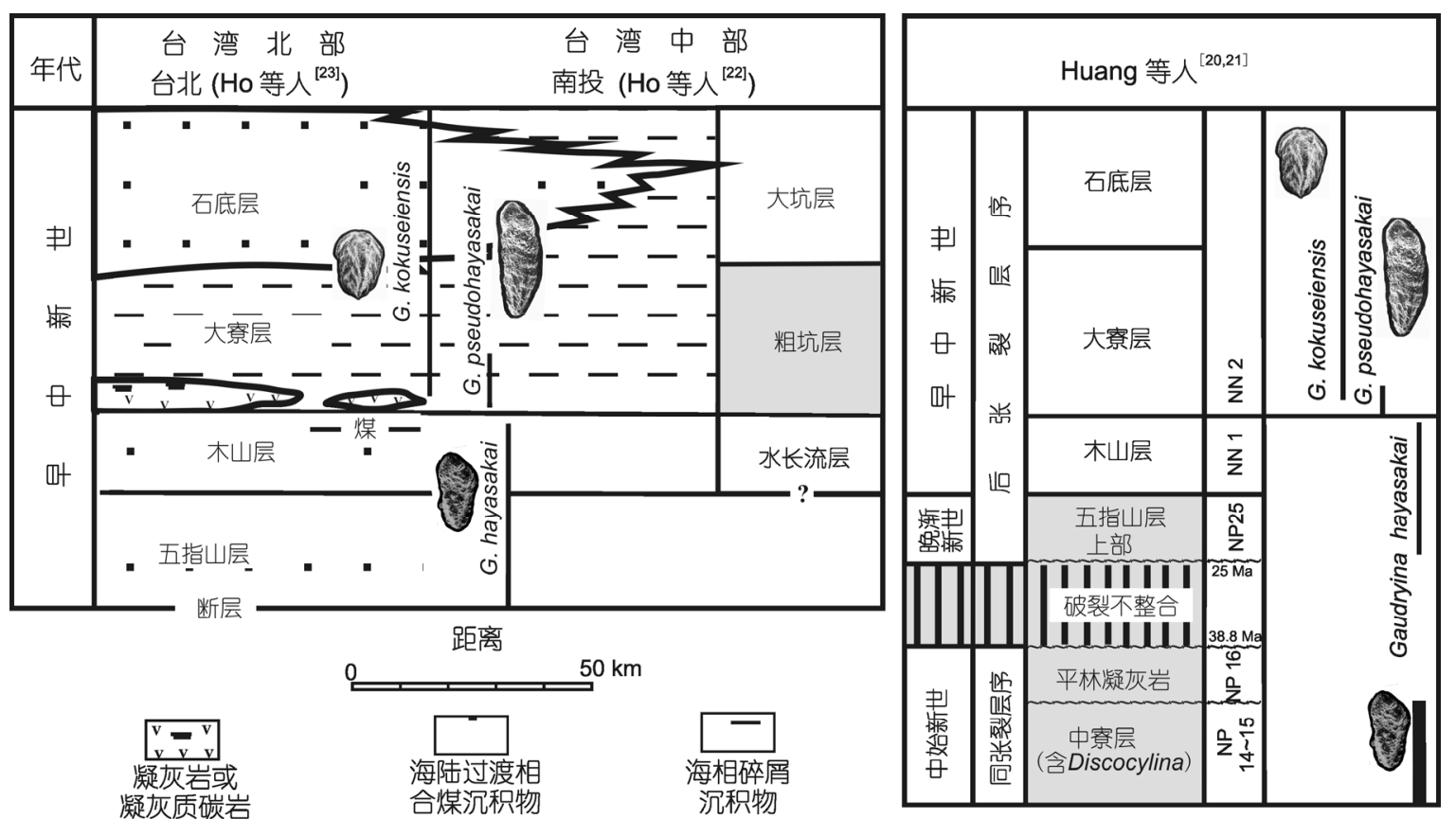

图 5 台湾中部南投县境西部麓山带粗坑背斜轴部剖面层序

原被命名为“中新世粗坑层”(122.23] (图左侧灰阶部分), 其中所含凝灰岩被认为对比于台湾北部的中新世公馆凝灰岩. 后经微体古生物研究包括 底栖有孔虫化石 Gaudryina 演化系列及钙质超微化石分析, 证实“中新世粗坑层”必须修正为 3 套独立岩性地层单位(图右侧对应灰阶): 后张裂 层序的最晚渐新世五指山层(最上部), 及同张裂层序的中始新世平林凝灰岩及中寮层 ${ }^{[20,21]}$

sella-dispansa 大型有孔虫化石，这些大型有孔虫化 石保存极为良好, 在大型有孔虫层位之上的薄砂/叶

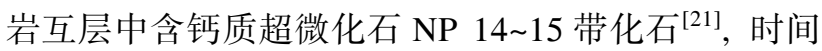
也与上覆平林凝灰岩 $38.8 \pm 1 \mathrm{Ma}$ 的定年结果或钻质 超微化石 NP 16 带相吻合 ${ }^{[20]}$.

渐新世最晚期五指山层(最上部; NP 25 带; 25 $\mathrm{Ma})$ 及以上中新世层序为新近纪后张裂层序, 中始新 世平林凝灰岩及中寮层为古近纪同张裂层序，两者 间为破裂不整合面(25 39 Ma)，缺失了约 $14 \mathrm{Ma}$ 的地 层记录(图 5).

\section{3 雪山山脉层序}

雪山山脉位于西部麓山带屈尺断层以东, 中央 山脉梨山断层以西(图 1), 主要由古近纪硬叶岩、砂 岩、板岩组成. 雪山山脉北部层序由上而下为: 木山 层、大桶山层、粗窟层、干沟层(合称上部乌来群)、 四棱砂岩及西村层(合称下部乌来群; 图 6). 到了台 湾中部的雪山山脉南段, 由于北港基盘高区的存在 (图 1), 渐新统-中新统的沉积速率降低到台湾北部的 $1 / 2 \sim 1 / 3^{[27]}$, 层序由上而下改为木山层、水长流层(相 当于雪山山脉北部的上部乌来群)、白冷层(相当于下
部乌来群；图 6). 1980 年以前的地质调查及微体古生 物研究, 一般认为不论在雪山山脉北段或南段, 始新 统-渐新统为连续沉积, 且渐新世上部乌来群整合覆 盖于始新世-早渐新世(事实上缺乏直接化石证据)四 棱砂岩或白冷层之上 ${ }^{[28]}$ (图 6 左). 上部乌来群为黑色 硬叶岩-粉砂岩, 富含浅海相化石 ${ }^{[29,30]}$ 的陆棚相沉积 环境, 而四棱砂岩或白冷层为砾-粗粒-细粒砂岩, 夹 碳质叶岩, 富含植物茎、叶化石的辫状河流-沼泽相 的沉积环境; 上部乌来群为平整层理，而四棱砂岩或 白冷层则呈现大规模交错层理，显示两者间有极明 显的沉积环境差异(图 6).

上部乌来群: 上部乌来群为浅海陆棚相连续沉 积, 富含浅海相化石(图 6,7), 属于晚渐新世-最早中 新世石嘈阶底栖有孔虫化石 Gaudryina hayasakai 带 ${ }^{[29]}$, 相当于浮游有孔虫生物地层的 $\mathrm{P} 20(=\mathrm{N} 1$ 带) $\mathrm{N} 4^{[24,28]}$ 或钙质超微化石的 NP23 NN1 带 ${ }^{[30]}$.

四棱砂岩：雪山山脉为典型褶皱-逆冲构造，在 雪山山脉北段紧接于上部乌来群以下的厚层细砾-粗 粒砂岩称为四棱砂岩, 而于雪山山脉南段称为白冷 层. 四棱砂岩于北部横贯公路(图 1, E)出露完整层序, 分为 3 段岩性(图 S1): 上段厚层细砾-中细粒砂岩, 薄 


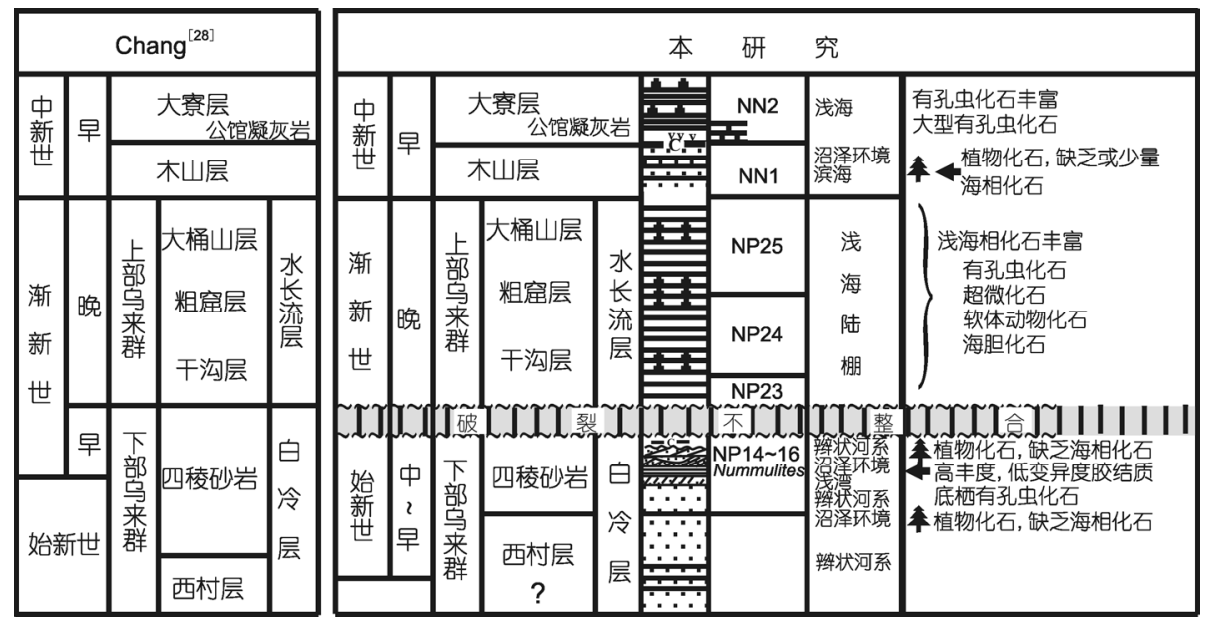

图 6 台湾雪山山脉层序

左图为传统认识 ${ }^{[28]}$, 右图为本研究结果, 表明上部乌来群与下部乌来群间为破裂不整合面

缟状粉砂岩及碳质叶岩 (270 m 厚), 含数薄煤层(每层 $\sim 5 \mathrm{~cm}$ 厚), 具波痕及交错层理, 在砾-粗粒砂层底部 具河道侵蚀槽沟构造(图 S2); 中段( 100 m 厚) 为厚 层叶岩; 下段(635 m 厚)为厚层细砾-中细粒砂岩, 波 痕薄缟状粉砂岩及碳质叶岩 ${ }^{[31]}$.

四棱砂岩上段及下段碳质叶岩含丰富植物草根 及树叶化石, 有孔虫化石极为稀少, 甚或完全缺乏 (图 6, S1, S2). 交错层理及水道构造常见于厚层砂岩 底部. 岩性特征, 沉积构造及化石内容均指示为陆相 辫状河-沼泽沉积环境(图 6). 中段厚层碳质叶岩中则 含碳物质及高丰度-低变异的胶结质底栖有孔虫化石, 占全体化石总个数 $95 \%$ 以上, 以 Cyclammina pacifica Beck, Cyclammina tani Ishizaki, Bathysiphon eocenicus Cushman and Hana, Martinottiella communis (d'Orbigny), Gaudryina hayasakai Chang 及 Cribrostomoides sp. 为主, 伴随少量钙质有孔虫 (图 S3), 但不含任何浮 游化石, 显示为低溶解钙, 低盐度之半咸水河口-半 封闭浅海湾沉积环境 ${ }^{[31,32]}$. 下段厚中-细粒石英砂岩 及薄缟状粉砂岩 (635 m 厚), 不含海相化石, 但含丰 富植物草根及树叶化石, 为陆相辫状河系沉积. 在雪 山山脉北段的北宜公路剖面(图 1,D)四棱砂岩的上部 及雪山山脉南段的国姓北港溪剖面(图 1, F)白冷层中, 曾发现淡水类软件动物化石 Corbicula ${ }^{[33]}$.

除北部横贯公路剖面外, 雪山山脉内其他研究 剖面 ${ }^{[32,34]}$ (南势溪剖面, 北势溪剖面, 北宜公路剖面, 龙洞岬剖面, 北港溪剖面; 图 1,S1) 四棱砂岩上段或 白冷层上段常出现可达 $3 \sim 5 \mathrm{~cm}$ 直径的圆-半圆砾, 具
大规模交错层理(图 S2 (b) (d)), 并缺乏海相化石, 仅 在南势溪剖面及北部横贯公路剖面发现以胶结质 Cyclammina pacifica Beck 和 Bathysiphon eocenicus Cushman \& Hanna 的小型底栖有孔虫化石 ${ }^{[32,34]}$. 南势 溪工程钻井(图 S1(b)) 四棱砂岩上部岩心发现被风化 溶蚀残余的一个大型有孔虫 Nummulites sp.化石可以 辨认(图 7(b)), 伴随外壳受到溶解的浅海相软件动物 化石印模, 及化石溶蚀空洞密集带, 推测为大型有孔 虫 Nummulites 密集带 ${ }^{[32]}$.

北宜公路石牌站附近地质探井所得四棱砂岩上 部岩心(图 7(c), PH-29-1; 图 S1(d)), 岩性以中-厚层 砾, 粗粒-细粒石英砂岩, 夹薄碳质粉砂岩及碳质叶 岩, 除在碳质粉砂岩中发现少量半咸水有孔虫 Trochammina inflata (Montagu) 外, 大部分岩心全不 含小型有孔虫化石, 但有植物茎叶化石, 显示为辫状 河-沼泽陆相沉积环境 ${ }^{[32]}$. 此岩心在细-中粒砂岩中保 存丰富大型有孔虫 Nummulites junbarensis Matsumaru 化石密集带 ${ }^{[32,35]}$ (图 7(c)). N. junbarensis 为 $N$. exilis 族, 发现于日本九洲早-中始新世 Akashimisaki Formation (钙质超微化石中始新世 NP 14 带 $^{[36]}$ )及台 湾中部雪山山脉南段的白冷层 ${ }^{[37]}$. 除此之外雪山山 脉北段的郡坑溪剖面(图 1, G)白冷层中发现始新世大 型有孔虫 Assilina formosensis 化石 ${ }^{[38]}$ 及中始新世钙 质超微化石 NP14 15 带 ${ }^{[39]}$ 化石.

北部横贯公路剖面四棱砂岩最上部一个极为特 殊的碳质粉砂岩标本(标本 NH-102, 图 S1(e))中含丰 富浮游有孔虫化石 ${ }^{[31,32]}$. 很可惜这些化石明显受到 


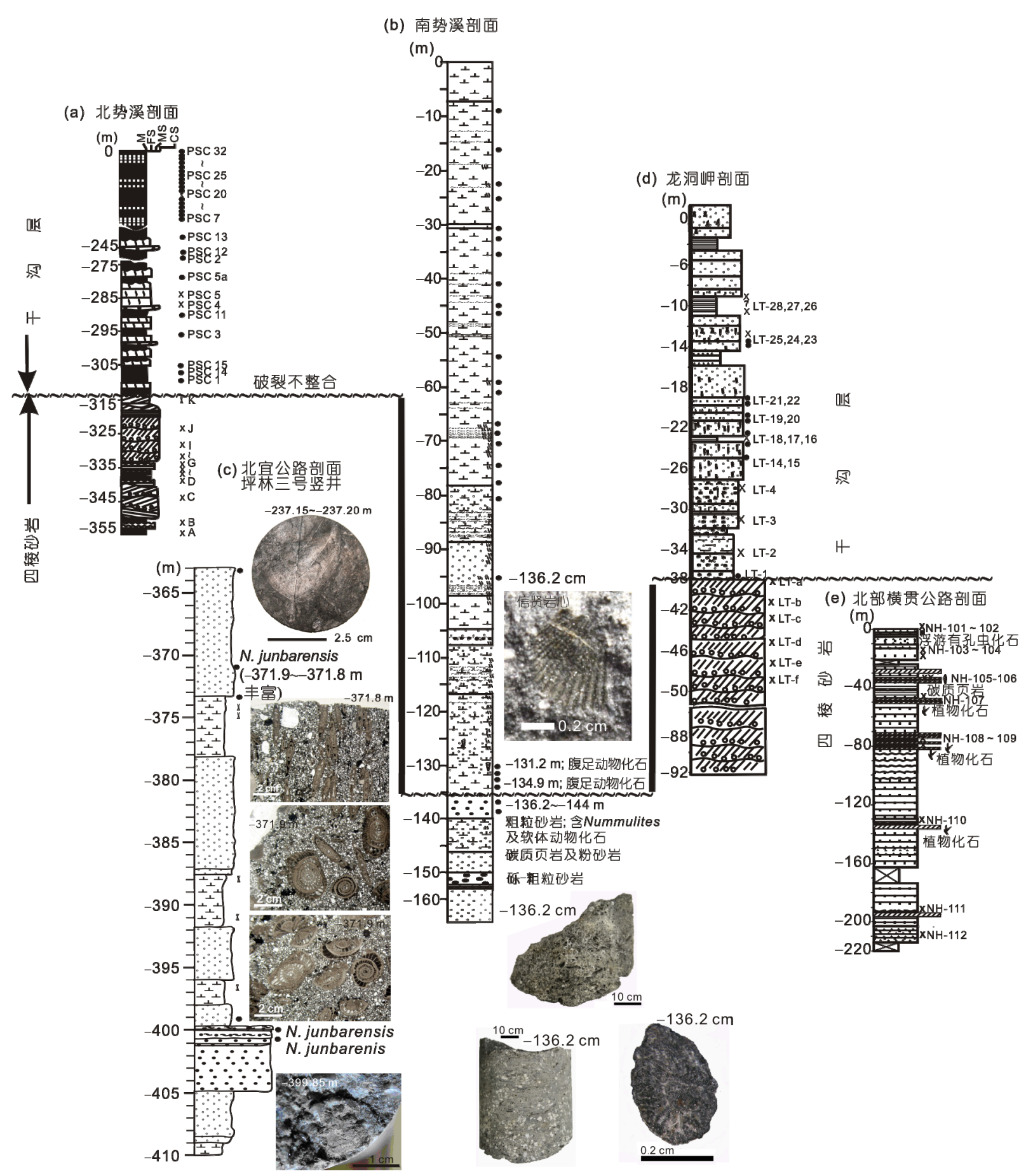

图 7 雪山山脉北段 5 个研究剖面中干沟层下部与四棱砂岩上部岩层柱状及微体化石研究标本层位

-, 含有孔虫化石; X, 缺乏有孔虫化石. 比较干沟层与四棱砂岩无论在岩性、沉积环境及化石组合均有明显差异. 波浪线为上部乌来群与下部 乌来群间的破裂不整合面

溶解影响，钙质外壳均没有保存(因此也不含钙质超 微化石)，只剩内模(图 S2(a))，因此鉴定发生困难，只 能依化石若干明显特征(如壳体大小、房室数目、房室
旋转)加以鉴定，同时也只能将近似种合并成一个 族群：包括只局限于中始新世者 ${ }^{[40,41]}$, 如：Orbulinoides (?)(末现面 LAD: 40.1 Ma, P13带), Turborotalia 
frontosa (Subbotina)? ( LAD: $39.3 \mathrm{Ma}$ ), Subbotina linaperta (Finlay)(LAD: $37.7 \mathrm{Ma}$ ), 或自中始新世延续人 渐新世存在者, 如 Turborotalia cerroazulensis (Cole) (LAD: $33.8 \mathrm{Ma}$ ), Pseudohastigerina spp.(LAD: 32.0 Ma), Turborotalia ampliapertura (LAD: $30.3 \mathrm{Ma}$ ), Chiloguembelina sp. (LAD: $28.5 \mathrm{Ma}$ ), Catapsydrax unicavus Bolli, Loeblich and Tappan, Subbotina crociapertura Blow, Subbotina yeguaensis (Weinzierl and Applin), Globigerinatheka (?) spp., Dentoglobigerina galavisi - pseudovenezuelana group. 但是可以确定此 $<20 \mathrm{~cm}$ 厚的碳质粉砂岩中不存在常见于上部乌来群 的渐新世特征种, 如 Globigerina ciperoensis 或 $G$. angulisuturalis.

综合北宜公路剖面四棱砂岩及白冷层含有大型 有孔虫 Nummulites junbarensis 货币虫化石, 南势溪 剖面 Nummulites sp., 郡坑溪剖面中含始新世大型有 孔虫Assilina 及 NP14 16 带超微化石及北部横贯公路 四棱砂岩标准剖面中含有始新世的浮游有孔虫化石 一同纳人考虑, 则可以将四棱砂岩和白冷层的沉积地 质时代局限于中始新世(图 6), 相当于西部麓山带粗
坑背斜平林凝灰岩 $(38.8 \pm 1 \mathrm{Ma} ; \mathrm{NP} 16$ 带)及中寮层 (含 大型有孔虫化石 Discocyclina expansa ex.inter. selladispansa 及 NP14 15 带钙质超微化石).

\section{4 中央山脉南部横贯公路剖面层序}

南部横贯公路(图 1, L)西起西部麓山带南段(台 南盆地)甲仙乡, 向东穿过荖浓断层进人中央山脉南 段. 荸浓断层以西属于台南盆地(禇皱-逆冲带), 出露 上新世-更新世前陆盆地层序及中新世被动式亚洲大 陆边缘浅海相层序; 荖浓断层以东为中央山脉中新 世增生楔(图 1). 南部横贯公路剖面自梅山以东到哑 口间, 自上而下划分为 4 个不同地层(图 8 左): 中新 世梅山层和礼观层(板岩-粉砂岩, 原为陆坡浊流沉积; 庐山阶), 始新世桧谷层 ${ }^{[22]}$ (砂岩-石灰岩-板岩; 毕禄 山阶 ${ }^{[28]}$, 及古生代(?)-中生代大南澳群片岩-大理岩千枚岩.

梅山层为中新世中期沉积 $\left(\right.$ 相当于庐山阶 ${ }^{[43]}$ )含 钻质超微化石 NN4 7 带 ${ }^{[44]}$; 早渐新世-中新世早-中期

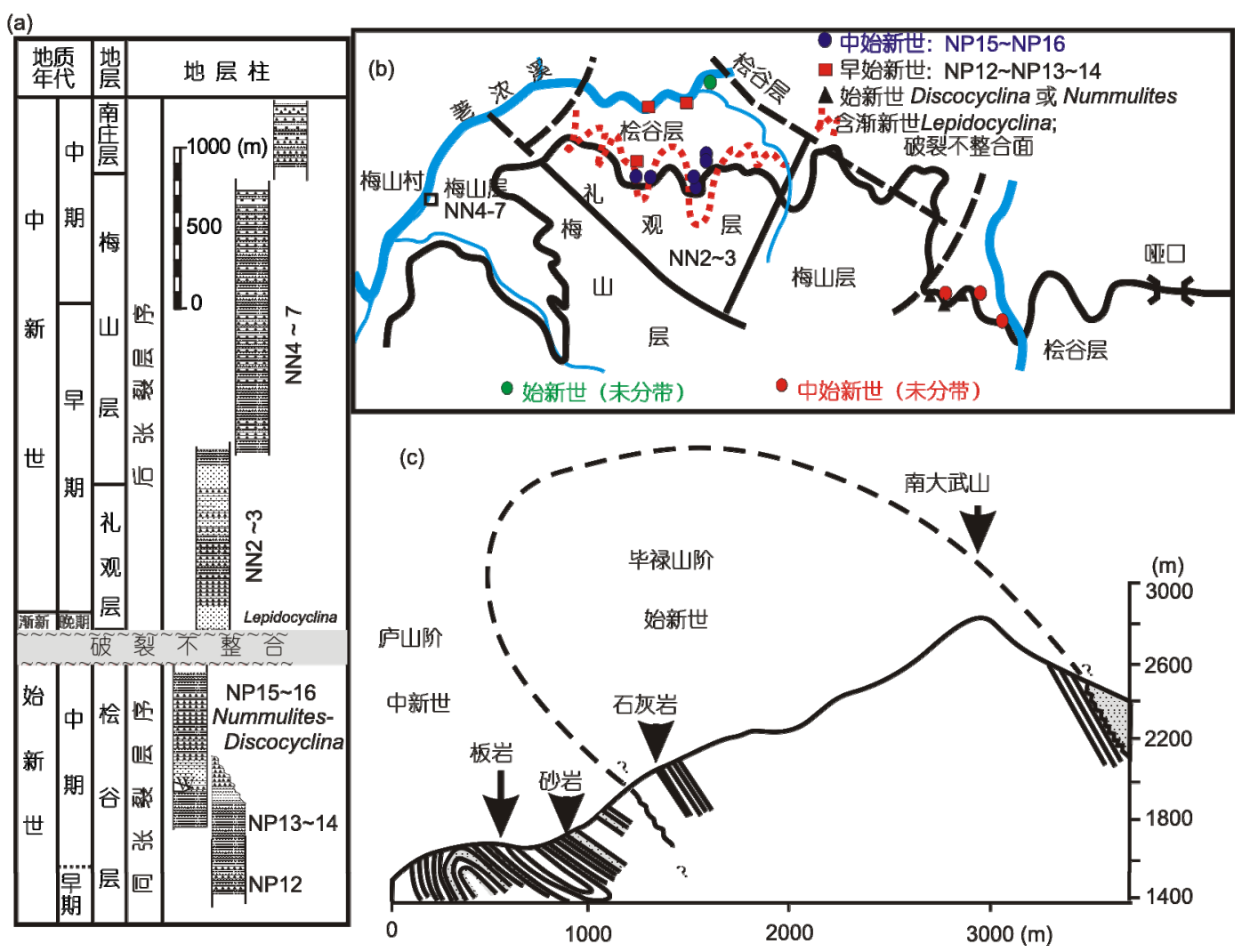

图 8 中央山脉南段南部横贯公路剖面层序 ${ }^{[42]}(a)$ 、化石层位 ${ }^{[43 ~ 45]}(b)$ 及南大武山剖面 ${ }^{[46]}(c)$ 说明在中始新世桧谷层与晚渐新世-早中新世礼观层间存在破裂不整合面 
礼观层以细砂岩为主, 为钙质超微化石 NN2 3 带 ${ }^{[44]}$; 另有厚约 $5 \mathrm{~m}$ 的石灰岩经褶皱后重复出露于礼观层 最下部(图 8), 此石灰岩含大型有孔虫 $\mathrm{Td}$ 阶化石 (Eulepidina-Lepidocyclina-Operculina-Heterostegina网状 Nummulite ${ }^{[45]}$ ), 不整合覆盖于早-中始新世板岩 的桧谷层之上 ${ }^{[42]}$. 桧谷层含始新世碧禄山阶大型有 孔虫化石 Nummulites-Discocyclina 变质砂岩-板岩 ${ }^{[43]}$ 及 NP12 16 带钙质超微化石 ${ }^{[44]}$ (图 8). 桧谷层内亦含 火山喷发岩, 并且不整合覆盖于晚古生代(?)-中生代 大南澳群变质片岩-大理岩-千枚岩之上 ${ }^{[28]}$.

南部横贯公路剖面中最年轻的梅山层及礼观层, 可以视为同一套原在南海北坡或台湾海峡南段台南 盆地沉积的晚渐新世-中新世后张裂层序(正如同西 部麓山带与雪山山脉诸研究剖面中的后张裂层序一 样), 而早-中始新世桧谷层则为古近纪同张裂层序 (对比于粗坑背斜剖面的平林凝灰岩-中寮层, 或雪山 山脉的下部乌来群), 两者间为破裂不整合面(图 8,9). 而古生代(?)-中生代大南澳群变质岩则应为前张裂基 盘, 始新世早-中期桧谷层与古生代(?)-中生代大南澳 群变质岩间为前张裂不整合面(图 9). 南部横贯公路 剖面具体而微的显示了台湾岛台东纵谷以西层序及 盆地类型的特征(图 2).

\section{5 台湾地区破裂不整合面时间}

台湾地区新生代层序研究工作表明无论是被动 大陆边缘尚未造山并且保存原来盆地形貌的台湾海 峡及西部海岸平原, 或已造山的西部麓山带及雪山 山脉, 或活跃大陆边缘中央山脉增生楔, 均可以清楚 认识出一个区域性破裂不整合面存在于中始新世-晚 渐新世之间，亦即位于浮游有孔虫 $\mathrm{N} 1$ 和 P13 带之间, 或钙质超微化石 NP23 和 NP16 带之间(图 9). 不但出 露的造山带剖面中从未发现晚始新世及早渐新世地 层, 台湾海峡及西部海岸平原的油气探勘钻井亦从 未发现此段地层，显示此破裂不整合面具有区域性 存在特征，不整合面时间位于 33 39 Ma 之间(图 9). 破裂不整合面时间距随着断陷盆地或地形构造高区 地位置之不同而异：在断陷盆地中心破裂不整合面 时间距小; 反之，在接近地形构造高区(如图 9 中北 港基盘高区 WG-1 井或中央山脉南大武山剖面 ${ }^{[46]}$; 图 8)，破裂不整合面时间距较大．此破裂不整合即传 统上所谓的埔里运动 ${ }^{[47]}$, 代表一次在亚洲大陆边缘 上的张裂构造活动，最后并导致南海海洋地壳的形 成，指示南海海洋地壳开始张裂形成的时间可能在 33 39 Ma 之间.

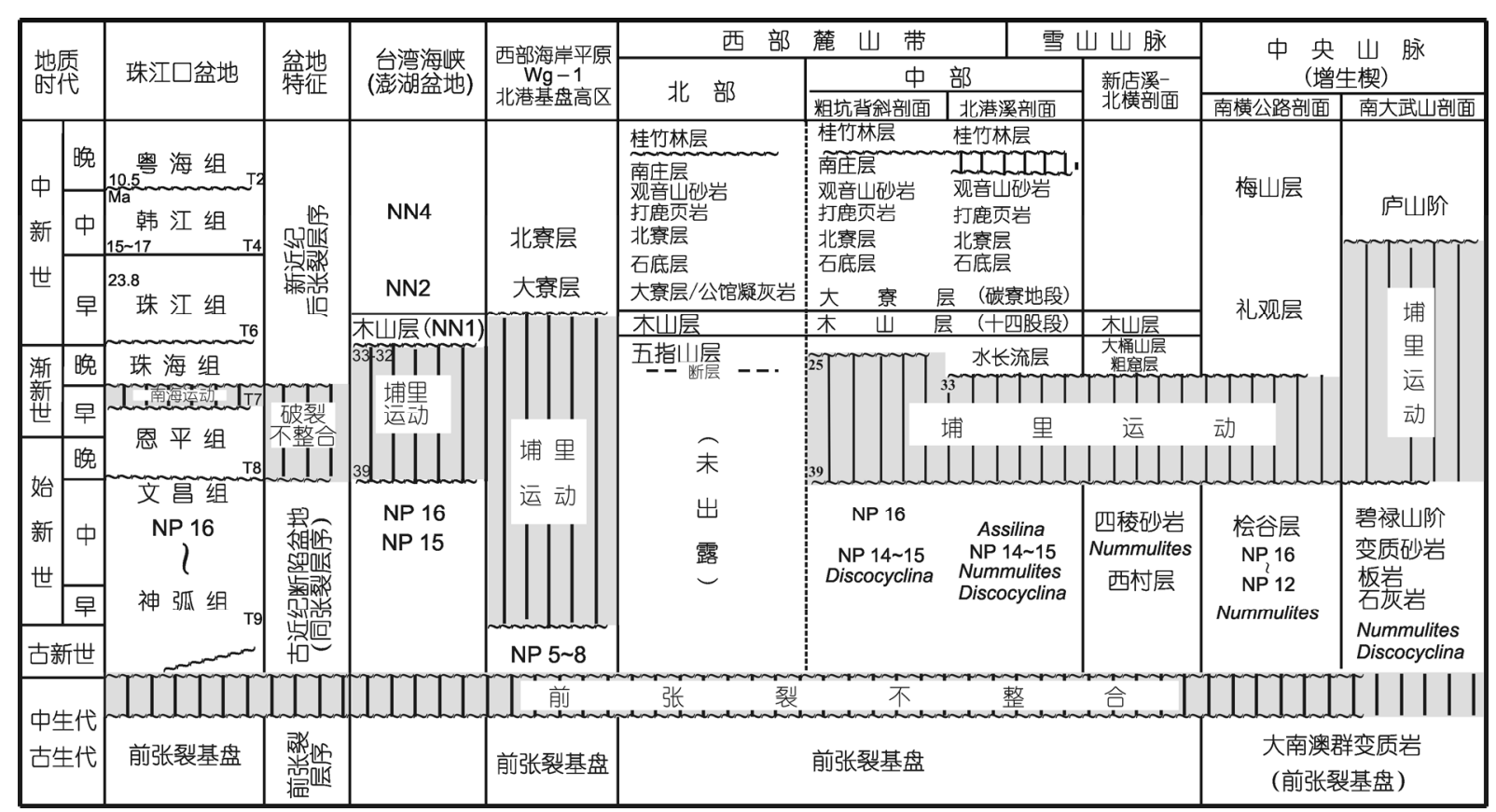

图 9 台湾造山带不同剖面破裂不整合面及前张裂不整合面之对比关系

此破裂不整合面在台湾地区称为埔里运动, 可以对比于珠江口盆地的 $\mathrm{T}_{7}$ 不整合面 ${ }^{[48}$ (南海运动) 


\section{2 南海深海区因中洋脊跃迁引起渐新世/中 新世间地层缺失及沉积崩滑在台湾浅海 相层序的响应}

\section{1 南海地区目前研究成果}

ODP 1148 站位岩心研究发现于 27.5 23 Ma 间的 渐新世/中新世界面附近, 在地震反射剖面图上出现 双强反射层 ${ }^{[10,11]}$ ，同时沉积相由晚渐新世的半远洋 泥向上改为白严泥或半远洋泥与白严团块混杂, 沉积 速率亦变慢, 并且有地层缺失及沉积崩滑特征 ${ }^{[10,12]}$, 认为是由于中洋脊于古地磁异常条带 $C_{7}(\sim 25 \mathrm{Ma})$ 时 发生跃迁的结果 ${ }^{[12,49]}$.

\section{2 台湾地区渐新世/中新世层序与沉积}

晚渐新世及中新世地层广泛出露于台湾岛西部 麓山带及雪山山脉(图 1, 2), 这些地层为典型受全球 海水面升降影响的浅海相被动大陆边缘后张裂层序 (图 2,4). 在台湾北部五指山层及木山层出露于基隆 外木山标准剖面(图 1, H). 过去学者对五指山层与木 山层的地层学研究已有充分成果报道. 五指山层的 最下部常为断层所截而出露不全. 在外木山剖面五 指山层(836 m 厚)主要由浅海相中-厚层复合式风暴 砂岩与薄砂岩/粉砂岩/叶岩互层组成, 含众多内陆棚 快速沉积环境下的遗迹化石 Thalasinoides-Ophiomorpha, 丰富软件动物化石, 底栖有孔虫 Gaudryina

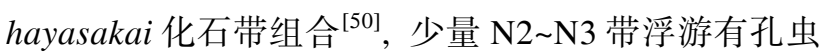
化石 ${ }^{[24]}$ 及 NP24 25 带钲质超微化石 ${ }^{[51]}$ (图 4). 五指山 层的最上部为 $70 \mathrm{~m}$ 厚泥岩, 含浮游有孔虫 N4 带指标 化石 Globigerinoides primordius 及 NP25 带钙质超微 化石 ${ }^{[24,26,51]}$ (图 4).

木山层至少 $650 \mathrm{~m}$ 厚, 岩性为厚层砂岩、粉砂岩 及薄叶岩, 最上部夹 3 层薄煤层 (每层 $<20 \mathrm{~cm}$ 厚). 木 山层为西部麓山带 3 个含煤系的下部煤系, 木山层的 海相化石比五指山层更少, 几乎不含浮游有孔虫及 钲质超微化石 (图 4). 木山层之上为大寮层/公馆凝灰 岩(浮游有孔虫化石 N5 带 ${ }^{[54]}$ 或钙质超微化石 NN2 带 $^{[51]}$, , 为浅海相沉积, 标记早中新世大海进的开始 (TB1 中的 1.4 期海进 $^{[53]}$ ). 因此推估木山层为浮游有 孔虫 N4/N5 交界, 或钙质超微化石的 NN1 带 ${ }^{[51]}$. 在 木山层之上公馆凝灰岩呈凸透镜状 $(0 \sim 200 \mathrm{~m})$, 介于 海相大寮层及海-陆过渡相木山层间(图 4). 部分凝灰
岩呈石灰质或间夹叶岩及粉砂岩层. 石灰质凝灰岩 含有孔虫和软件动物化石, 台湾中新世指标大型有 孔虫化石 Miogypsinoides 及 Miogypsina 属, 小型有 孔虫 Gaudryina pseudohayasakai Chang 及 G. kokuseiensis Ishizaki, 软件动物化石 Amussiopecten yabei (Nomura) 自公馆凝灰岩底部首度出现(图 4). 大寮层 为浅海相生物扰动强烈的细砂-粉砂岩及厚层泥岩, 含典型陆棚相化石, 其组合与公馆凝灰岩相同 ${ }^{[52]}$, 属 底栖有孔虫 Gaudryina pseudohayasakai 带及 Gaudryina kokuseiensis 带, 但与五指山层-木山层的 Gaudryina hayasakai 带组合差异极明显 ${ }^{[50]}$ (图 4).

虽然五指山层在西部麓山带及雪山山脉有不同 地层称呼(如台湾北部西部麓山带称五指山层, 雪山 山脉北段及南段分别称大桶山层-粗坑层和水长流层), 但它总是整合在木山层之下. 在台湾中部国姓北港 溪剖面(图 1, F) 晚渐新世水长流层厚 $750 \mathrm{~m}$, 主要岩 性为硬叶岩, 间夹 1 5 cm 薄粉砂岩, 局部含 5 15 cm 细砂岩, 属底栖有孔虫 Gaudryina hayasakai 化石带, 浮游有孔虫 N1 N4 带[25] 或钙质超微化石 NP 23 25 带 ${ }^{[27]}$. 木山层 $\left(150 \mathrm{~m}\right.$ 厚)整合覆盖水长流层之上 ${ }^{[24,27]}$, 为海-陆交互相沉积, 由厚层复合式风暴砂层和具交 错层理海滨砂层为主, 几乎缺乏在台湾中部常见的 薄煤层. 木山层中含少量底栖有孔虫化石, 组合与水 长流层类似, 同属石嘈阶 Gaudryina hayasakai 化石带. 虽然木山层几乎不含浮游化石, 但位于水长流层最 上部浮游有孔虫 Globigerinoides primordius 带(N4)底 部以上, 且整合在大寮层(浮游有孔虫 N5 带或钙质超 微化石 NN2 带 ${ }^{[27]}$ 之下, 指示台湾中部木山层与在台 湾北部标准剖面的木山层完全一致，处于浮游有孔 虫 N4 带内或钙质超微化石的 NN1 带内的最早中新世.

在台湾北部五指山层至大寮层底部共 1900 m 厚的层序中, 或台湾中部国姓北港溪剖面水长流层大寮层底部共 1000 m 厚层序中, 晚渐新世-早中新 世 N2 N5 带或 NP24 NN2 带中间并未发现明显地层 缺失或沉积崩滑特征 ${ }^{[54]}$, 只有沉积环境估计由内陆 棚-海滨逐渐变浅为沼泽环境的改变. 故本文结论南 海北坡浅海陆棚区缺乏如深海区 ODP1148 站位在渐 新世/中新世界面所记录的地层缺失或滑蹋事件记录.

虽然台湾北部及中部出露的西部麓山带晚渐新 世/早中新世层序并不显示两者间有地层的缺失或崩 滑沉积现象, 但却有明显生物群变化. 此生物群变化 可能是由于古气候的差异引起. 由于台湾地区后张 
裂层序完全处于被动大陆边缘沉积的内陆棚-沼泽环 境, 但大型有孔虫化石只存在于公馆凝灰岩以上的 中新统, 但未发现于木山层及以下地层, 指示古气候/ 古环境可能由晚渐新世 $25 \mathrm{Ma}$ 以前相对较凉的内陆 棚海退相浅海环境(故缺乏大型有孔虫化石), 慢慢转 变为 $23.5 \mathrm{Ma}$ 以后温暖的早中新世大寮层/公馆凝灰 岩海进相陆棚环境(故含大型有孔虫化石; 图 4).

\section{3 中新世中期南海底栖有孔虫氧同位素地 层记录及台湾地区化石群变化的响应}

南海 1148 站位得到西太平洋最完整连续中新世 (25 Ma)以来高分辨率底栖有孔虫 Cibicidoides wuellerstorfi 氧碳同位素地层 ${ }^{[13,14]}$ (图 10). 其中氧同位素地
层最大特征包括 3 段阶梯式正位移: (I)阶早-中中新 世(24 14 Ma), (II)阶中中新世-早上新世(14 4 Ma), 及(III)阶早上新世以来(4 0 Ma) (图 8), 表明全球气 候自中中新世逐渐变冷趋势. 由(I)阶进人(II)阶的转 换期，即 14.4 13.6 Ma 时，氧同位素值呈现剧烈快速 变正值, 震幅达到 $0.9 \%$, 反映了南极冰盖重大快速 扩张(图 10), 全球底层水显著变冷和海平面下降现 象 ${ }^{[53,55,56]}$. 并且中中新世 $17.2 \sim 14.5 \mathrm{Ma}$ 及晚中新世 10.2 9.4 Ma 时氧同位素值分别达到中新世的最负值 及最正值，也分别代表中新世时的最佳气候暖期及 最冷期(图 10).

在台湾中新世浅海沉积环境固然不能得到南海 深海盆的古海洋讯息, 但是 ODP 1148 站位的底栖有 孔虫氧同位素曲线大致上是平行于浮游有孔虫氧同

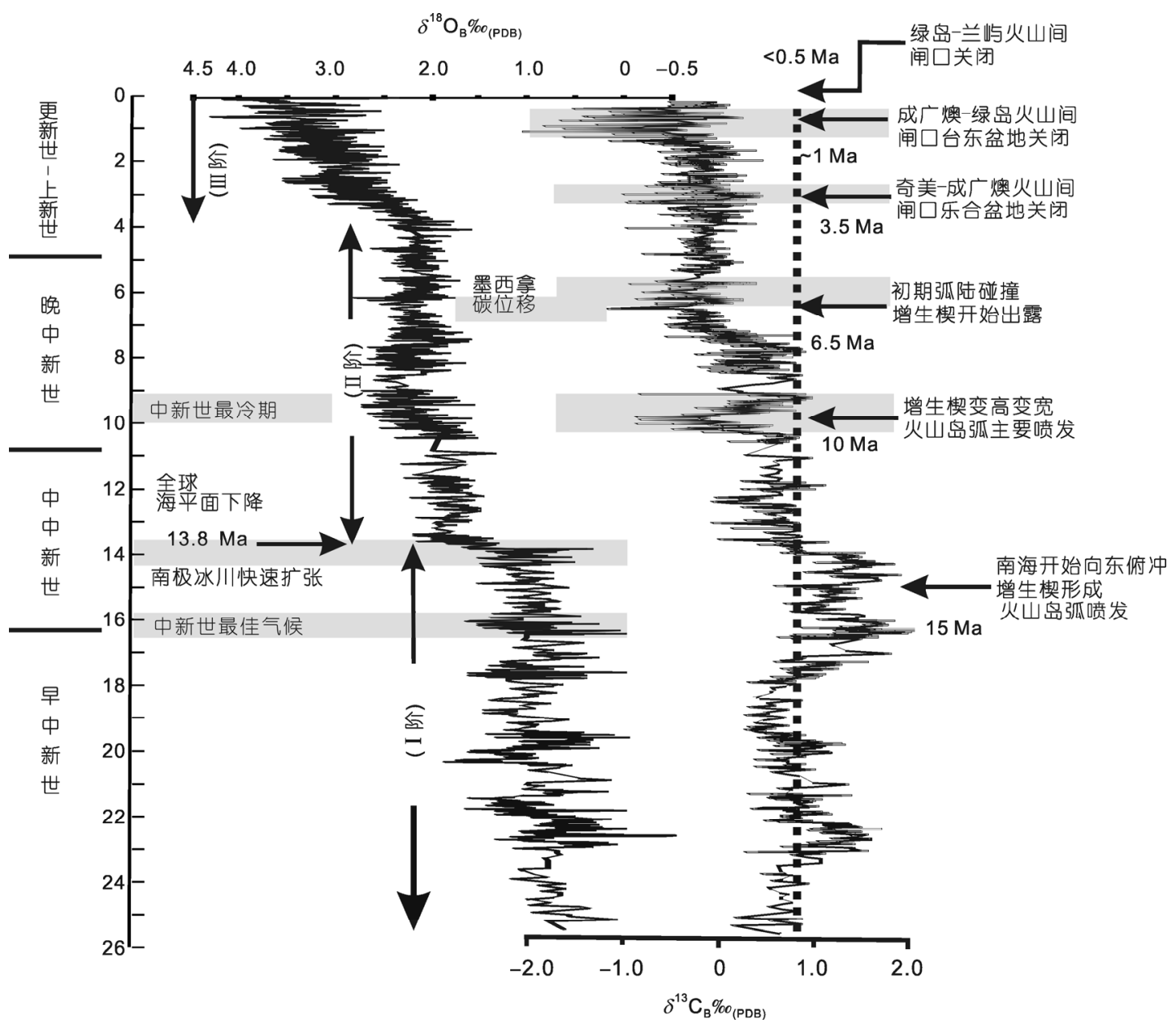

图 10 ODP 1148 站位 $26 \mathrm{Ma}$ 以来底栖有孔虫氧、碳同位素地层记录 ${ }^{[14,15]}$

1148 站位氧同位素地层呈三阶正位移. 另外右侧为 1148 站位碳同位素地层自中新世以来负位移及与台湾恒春半岛-中央山脉增生楔和海岸 山脉弧前盆地-火山岛弧构造演化时间关系 
位素曲线 ${ }^{[14,15]}$, 表示均受到冰盖体积变化的影响. 而 冰盖体积的变化又影响了全球海水面升降及气候的 变化, 也就影响到台湾地区中新世中期的沉积层序 及所含化石群的变化. 台湾地区中新世浅海相地层 有孔虫化石群最大变化发生于中中新世进入晚中新 世时期 ${ }^{[57]}$ (图 11, 西部麓山带出磺坑剖面为代表; 图 $1, \mathrm{~J})$, 与南海底栖有孔虫氧同位素地层由第(I)阶进人 第(II)阶的转化阶段(15 12 Ma)几乎同时(图 11). 出 磺坑剖面的沉积相表明由中中新世最佳气候暖期, 也是海平面达到最高时期的上陆坡打鹿叶岩(图 11; 超微化石 NN4 5 带; 16 14.5 Ma), 向上明显逐渐海 退转换为 14.5 13.5 $\mathrm{Ma}$ 的内陆棚相观音山砂岩, 再 向上到因南极冰盖快速扩张而导致全球海水面大降 的海滨砂-沼泽-陆相含煤的南庄层(图 11). 甚至于在 构造地形高区, 因大海退导致南庄层暴露而缺失(如 台湾中部国姓北港溪剖面, 图 $1, \mathrm{~F})^{[25]}$.

中中新世/晚中新世交界附近也发生台湾中新世 层序中最明显的化石群组合变化 ${ }^{[57]}$ (图 11), 除了化 石丰度(底栖有孔虫化石个数/每 $200 \mathrm{~g}$ 沉积物)自打鹿 叶岩(16 14.5 Ma)往上逐渐降低外, 底栖有孔虫化石 种数自打鹿叶岩含 40 20 种, 经观音山砂岩(14.5 13.5 $\mathrm{Ma})$ 减少到 $<10$ 种, 南庄层下部 $<2$ 种, 南庄层中部 12.9 10.2 Ma 时则完全没有海相化石, 一直到南庄层
最上部 10.2 Ma 底栖有孔虫化石才再出现(图 11). 随 着数量上的变化, 早-中中新世台湾地区特征底栖有 孔虫指标化石, 如 Textularia kansaiensis Ishizaki, $T$. akaminei Ishizaki, Lenticulina taluensis Chang, Bigenerina shihtiensis Chang, Gaudryina kokuseiensis Ishizaki, Guttulina pacifica ishizakii Chang, 也在 14 13 Ma 间观音山砂岩及南庄层最下部逐渐绝灭(图 11). 自南庄层上部(10.2 Ma)先由广盐性 Ammonia cf. japonica (Hada)和 A. altispira Qin and Lin 出现, 继之 生活于今日正常浅海洋环境陆棚的底栖有孔虫, 如 Sigmoidella subtaiwanica Nakamura, Asterorotalia yabei (Ishizaki), P. tikutoensis (Nakamura), Pseudorotalia schroeteriana (Parker and Jones), Bigenerina nodosaria d'Orbigny, B. taiwanica Nakamura, Asterorotalia inspinosa Huang, A. subtrispinosa (Nakamura), Textularia pseudokansaiensis Chang, T. alishanensis Chang 才出现(图 11). 这种老的早-中中新世底栖有 孔虫化石组合被新的晚中新世-现代底栖有孔虫化石 组合取代现象，在台湾称为“后打鹿阶生物间隙”或 “后庐山阶生物变化” ${ }^{[57,58]}$. 此化石群变化并非只是 由于海侵-海退的沉积环境改变因素所引起, 因为在 早中新世时由海进大寮层向上变为海退相石底层, 再改为中中新世海进北寮砂岩-打鹿叶岩过程中, 并

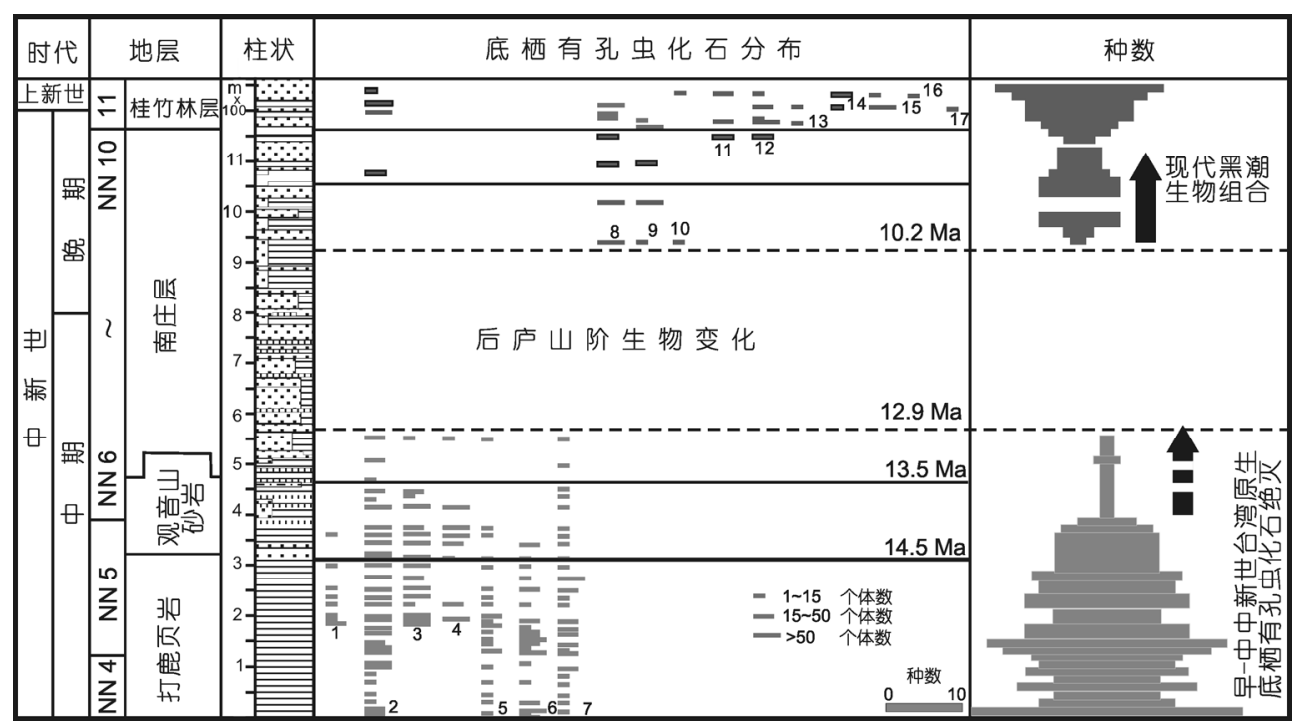

图 11 台湾西部麓山带中-晚中新世层序及后庐山阶生物组合变化 ${ }^{[57,58]}$

1, Textularia kansaiensis Ishizaki; 2, Heterolepa praecincta (Karrer); 3, Tesxtularia akaminei Murata; 4, Uvigerina nitidula Schwager; 5, Guttulina ishizakii Chang; 6, Bigenerina shihtiensis Chang; 7, Ammonia sp1.; 8, A. cf. japonica (Hada); 9, Ammonia altispira Qin and Lin; 10, Sigmoidella subtaiwanica Nakamura; 11, Textularia pseudokansaiensis Chang; 12, Asterorotalia yabei (Ishizaki) + A. gaimardii (d'Orbigny); 13, Asterorotalia inspinosa Huang; 14, A. sp., 15, A. subtrispinosa (Nakamura) ; 16, Bigenerina nodosaria d'Orbigny; 17, Pseudorotalia tikutoensis (Nakamura) 
未发生底栖有孔虫化石组合的改变 ${ }^{[58]}$.

由于晚中新世新出现的底栖有孔虫化石特征类 同于现代在东海外陆架区 ${ }^{[59]}$-台湾海峡-台湾西南海 域黑潮流经区的底栖有孔虫生物组合, 代表今日北 半球太平洋西边界流黑潮在晚中新世初期 12.9 10.2 $\mathrm{Ma}$ 期间被强化 ${ }^{[57]}$. 而黑潮强化的机制可能受控于 12 8 Ma 时澳大利亚大陆与印度尼西亚火山岛弧的 俯冲-碰撞构造, 使太平洋-印度洋穿越流路径关闭, 导致太平洋北赤道流向西流到菲律宾民答那峨岛时, 因地球自转而增加向北流量, 成为今日的黑潮 ${ }^{[57,60]}$. $10.2 \mathrm{Ma}$ 开始出现西太平洋黑潮现代浅海底栖有孔虫 生物组合现象, 与 ODP 289 站位爪哇地区在 $9 \mathrm{Ma}$ 时 也发生了底栖有孔虫化石重大转变, 产生了与现代 相似的组合 ${ }^{[56]}$, 推测两者间有古海洋变化的关联性. 这两个事件均发生在南极冰盖快速扩张的全球大冷 期之后, 显示在西太平洋在中/晚期中新世界面附近 的古海洋重组.

\section{4 台湾构造演化引起南海的半封闭}

\section{1 今日南海半封闭深海环流特征}

南海的深海盆水系由西太平洋的深层水 $(-1000$ -2500 m) 向西流，穿越台湾-吕宋岛间吕宋海峡的南 海海槛(包括北吕宋火山岛弧及恒春海脊增生楔)后, 下沉进人中央海盆底部. 因此 $-1500 \mathrm{~m}$ 以下南海的 海水溶氧值低于同一水深的西太平洋溶氧值 ${ }^{[61]}$. 台 湾岛与吕宋岛间的吕宋海峡存在恒春海脊增生楔及 北吕宋火山岛弧两个地质构造单元(图 1 右下插图). 显示现代南海的深层环流的形成, 明显与恒春海脊 增生楔及北吕宋火山岛弧的构造演化息息相关. 恒 春海脊增生楔自吕宋岛西侧海域(水深-2400 m) 向北 延伸到台湾南部海域(不及-200 $\mathrm{m}$ 水深), 然后出露 为恒春半岛-中央山脉, 南北延绵 $700 \mathrm{~km}$ 以上(图 1). 北吕宋火山岛弧自吕宋岛北部向北延伸，经巴布淹 岛-巴丹岛-兰屿-绿岛到台湾东部海岸山脉(图 1). 每 一个火山岛代表一独立火山喷发中心, 火山岛间有 火山岛闸口，如兰屿-丹巴岛间的巴士海峡，水深在 -2400 - $2600 \mathrm{~m}$, 为今日太平洋深层水团进人南海深 海盆的主要通道(图1). 因此, 下列 3 个构造发生时间, 敒关南海形成半封闭性边缘海的机制及古海洋特征 的改变: (1) 南海岩石圈开始向东俯冲形成增生楔及 火山岛弧两个地形高区的时间，(2) 恒春海脊出露为
恒春半岛-中央山脉的时间，及(3) 火山岛间闸口关 闭的时间.

\section{2 南海半封闭的古海洋记录}

ODP 1148 站位岩心的古海洋研究, 表明在 $16 \mathrm{Ma}$ 以前南海深海盆水的底栖有孔虫碳同位素值与太平 洋深海岩心记录一致, 但 $16 \mathrm{Ma}$ 以后则较太平洋岩心 平均值为负值 ${ }^{[14,62]}$. 影响深层水碳同位素值的因素 很多, 除了全球大气-海洋碳储库的变化有关外, 并 且与水团来源、流经路径、混合度及底层水年龄有关. 因此南海深海盆水底栖有孔虫碳同位素值随时间的 变化, 除了体现了全球海洋-大气的变化讯息外, 也 包含有南海本身底层水来源，流经路径、水团年龄及 水团混合的区域性因素. 只要将南海 ODP 1148 站位 底栖有孔虫氧-碳同位素地层与开放性大洋同时间内 底栖有孔虫氧-碳同位素地层比较，过滤掉彼此间相 同时间-相同变化讯息后，即可得知南海本身区域变 化的记录, 并找出引起变化的机制.

\section{3 半封闭的南海古海洋变化与恒春海脊增生楔 构造演化关系}

恒春海脊增生楔开始形成的时间及增生楔出露 海平面的时间，对南海半封闭的形成有重要意义. 前 者事件开始阻碍西太平洋底层水 $(-2500 \mathrm{~m}$ 以下)进人 南海, 而后者甚至于大大缩减至少 $400 \mathrm{~km}$ 宽 (即台 湾岛中央山脉增生楔长度)太平洋与南海表层水团的 交换通道. 恒春海脊增生楔开始形成的时间(或南海 开始向东俯冲的时间), 很难由增生楔本身的层序或 变形时间去推估，但可以由北吕宋火山岛弧最早的 喷发时间推论 ${ }^{[63]}$. 台湾东部海岸山脉及东南方海域 绿岛-兰屿-巴丹岛的北吕宋火山岛弧中可以采到的 岩石标本，并以各种可靠定年方法测得的最早火山 喷发活动时间为中中新世 $15 \sim 16 \mathrm{Ma}^{[64]}$, 指示中新世 中期(15 Ma)南海海洋岩石圈向东俯冲构造已经发生, 并且原来沉积在南海北坡被动大陆边缘陆棚-陆坡海盆的沉积物开始被铲刮入恒春海脊增生楔，增生 楔因此逐渐增大(变高也变宽; 图 12). 同时间北吕宋 火山岛弧也开始发生喷发, 两者均影响太平洋底层 水(>-2500 $\mathrm{m}$ 水深)进人南海的连通性，使得南海深 海水团可能变得比较停滞性，也可能导致了短时间 尺度上南海深层环流及化学性质(如碳同位素值)的 改变, 最后南海深海区底栖有孔虫的碳同位值比以 
前更趋向负值(图 10).

恒春半岛由 3 套岩层组成(图 12 左): 中-晚期中 新世时原在南海北坡陆棚-陆坡沉积的复理式浊流层, 于俯冲管道形成的晚中新世垦丁混杂岩, 及上新世更新世斜坡盆地浅海相泥-石灰岩-泻湖层序 ${ }^{[6]}$. 增生 楔内变形强烈最年轻浊流层为中新世最晚时代 (NN11 带; 8 Ma ${ }^{[65]}$, 指示增生楔在 15 8 Ma 期间已 发展成今日恒春海脊形貌(图 12,(a)). $6.5 \mathrm{Ma}$ 开始的 斜向弧陆碰撞，使得恒春海脊增生楔受到挤压而露 出海平面, 成为原始中央山脉, 并且接受侵蚀, 沉积 于今日西部麓山带前陆盆地 $(<6.5 \mathrm{Ma}$; 图 2), 或沉积 于不整合在增生楔之上的斜坡盆地(今日恒春西台地, 图 12(b))内马鞍山层(4.5- 1 Ma; 图 12(b) $)^{[6,63]}$. 因此, 在 4.5 4 Ma 时恒春半岛-中央山脉增生楔已具今日形 貌，西太平洋与南海水团的交换通道减少了台湾岛
中央山脉 $400 \mathrm{~km}$ 的宽度. 换句话说，南海今日的环 流体系可能自 $4.5 \mathrm{Ma}$ 即已形成了, 这也使得 1148 站 位的底栖有孔虫化石碳同位素值在第(III)阶( $<4 \mathrm{Ma}$ )变 得更负值(图 10), 也指示除了全球性的墨西拿盐度危 机事件作用外，恒春海脊增生楔的构造演化对南海 底层水的古海洋变化起了重要的控制角色(图 10).

\section{4 半封闭的南海古海洋变化与北吕宋火山岛弧 构造演化关系}

南海海洋岩石圈向东俯冲导致自中新世中期以 来吕宋火山岛弧的喷发. 北吕宋火山岛弧由南-北向 排列的火山岛链组成, 包括已加附到海岸山脉北段 的奇美火山岛及南段的成广燠火山岛 ${ }^{[66]}$, 及现在仍 然在台湾东南海域的绿岛、兰屿、巴丹岛、巴布淹岛 (图 1). 喷发的火山角砾岩自花东海盆 $-5500 \mathrm{~m}$ 水深
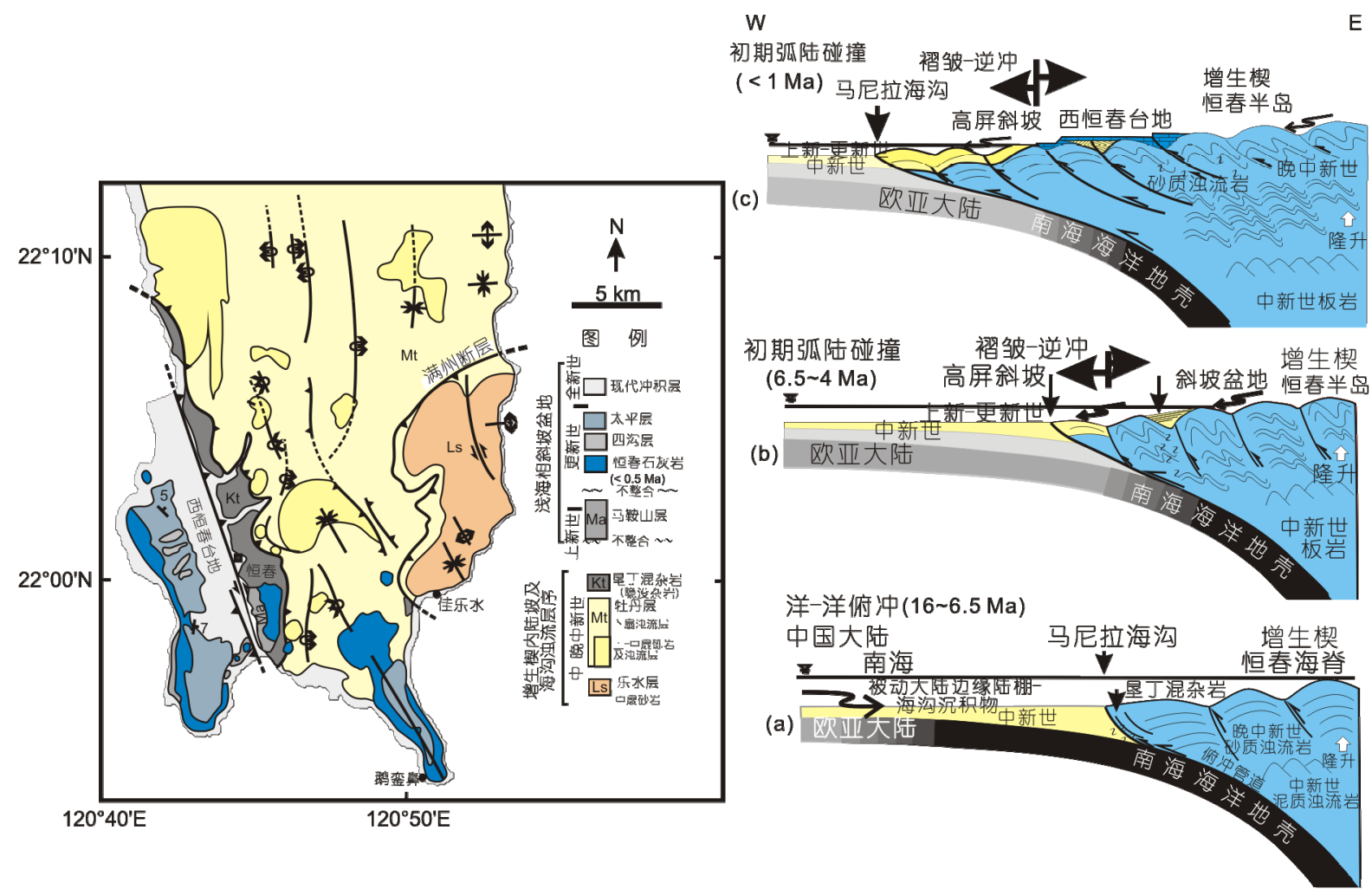

图 12 恒春半岛增生楔构造地层图及增生楔构造演化(修改自文献[6,63])

恒春半岛增生楔由 3 套地层构造单元组成: 变形强烈的晚中新世复理式陆坡浊流层、晚中新世垦丁混杂岩及上新世-更新世浅海斜坡盆地(左 图). 恒春半岛的构造演化经历洋-洋俯冲及初期弧陆碰撞构造两阶段(图 1): (a) 于 16 6.5 Ma 洋-洋俯冲构造阶段, 南海海洋岩石圈向东俯冲形 成恒春海脊增生楔; (b) 菲律宾海板块向西北方向移动导致 $6.5 \mathrm{Ma}$ 开始弧陆碰撞发生. 在初期弧陆碰撞构造阶段(6.5 4 Ma), 恒春海脊增生楔 出露为原始中央山脉, 并接受侵蚀提供沉积堆积于增生楔之上的斜坡盆地及当时马尼拉海沟以西的前陆盆地. 原来的被动大陆边缘沉积物也 被变形为增生楔一部分, 使马尼拉海沟位置向西迁移, 并开始失去海沟俯冲角色转移为褶皱-逆冲带前缘断层; (c) < $1 \mathrm{Ma}$ 现在活跃弧陆碰撞构 造使斜坡盆地层序倾斜及抬升成西恒春西台地, 并且前陆盆地沉积物变形为今日台湾岛西南外海高屏斜坡的禇皱-逆冲带 
逐渐向上堆积而突出于海平面之上, 形成太平洋深 层水团向西流人南海中央海盆的第一道天然障碍. 火 山岛彼此间为火山岛闸口，此闸口向西连通到北吕宋 海槽弧前盆地(水深-2500 -3000 m; 图 1), 成为今日 太平洋深层水团进人南海中央海盆之主要通道. 因 此, 火山岛闸口数目越多, 闸口越深越宽, 越有利于 太平洋深层水团进人南海中央海盆; 反之, 则不利.

海岸山脉由 4 个残留弧前盆地, 2 个独立火山岛, 2 个弧上盆地, 及 1 个由弧前盆地因碰撞剪裂变形的 利吉混杂岩组成 ${ }^{[7,66]}$ (图 13). 4 个残留弧前盆地由上新 世-更新世浊流层沉积(包括三角洲扇及深海扇砾石 层), 沉积物主要侵蚀自 $6.5 \mathrm{Ma}$ 以来隆升出海平面之 上的中央山脉增生楔, 少部分来自东边的火山岛弧. 残留弧前盆地大小差异很大, 自北而南为: 水琏盆地 (大)、乐合盆地(小)、泰源盆地(大)及台东盆地(小). 两个独立火山岛为奇美火山岛(北)及成广燠火山岛 (南). 因斜向弧陆碰撞, 这两个独立火山岛发生走滑 拉张, 形成弧上盆地 ${ }^{[66]}$ (图 13). 残留弧前盆地原位于 火山岛的西侧, 且南-北向连续为北吕宋海槽弧前盆 地的一部分. 弧前盆地西侧于 $3.5 \mathrm{Ma}$ 发生向东背逆冲 构造, 产生花东海脊 ${ }^{[66,67]}$ (今日水深-1400 m; 图 1, 14). 4 个残留弧前盆地中的 2 个小盆地位置也正位于火山 岛间闸口(乐合盆地位于奇美火山岛与成广燠火山岛 间的闸口，台东盆地位于成广燠火山岛与目前尚在 台湾东南海域的绿岛间的闸口; 图 13).

持续向西北方向前进的菲律宾海板块导致北吕 宋火山岛弧与俯冲的欧亚大陆边缘发生斜向弧陆碰 撞, 使初期弧陆碰撞带内的花东海脊继续向上变形 抬升，并且把位在两个火山岛间闸口的沉积物也一 并变形且抬升成为花东海脊的一部份 (如图 14, X 处), 一旦火山岛间的闸口半封闭, 北吕宋海槽就被分隔 成南-北向排列的残留弧前盆地(图 14). 目前在初期 弧陆碰撞带内的绿岛-兰屿火山岛间的闸口正变形封 闭中(图 14). 此变形的火山岛间闸口作用类似一个沉 积构造坝, 阻碍现代沉积物不能越过此沉积构造坝, 转而沿台东峡谷被往东带人台湾东侧海域的花东海 盆(图 14).

乐合残留弧前盆地内的浊流层序经浮游有孔虫 及钻质超微化石研究为 4.2 3.6 Ma 时沉积 ${ }^{[69]}$, 表明奇 美火山岛及成广燠火山岛间闸口的乐合盆地于 $3.5 \mathrm{Ma}$ 时变形、抬升、封闭成沉积构造坝. 因此, 盆地内没 有比 $3.5 \mathrm{Ma}$ 还年轻的地层 ${ }^{\left[{ }^{[69]}\right.}$, 也使得晚上新世巨厚

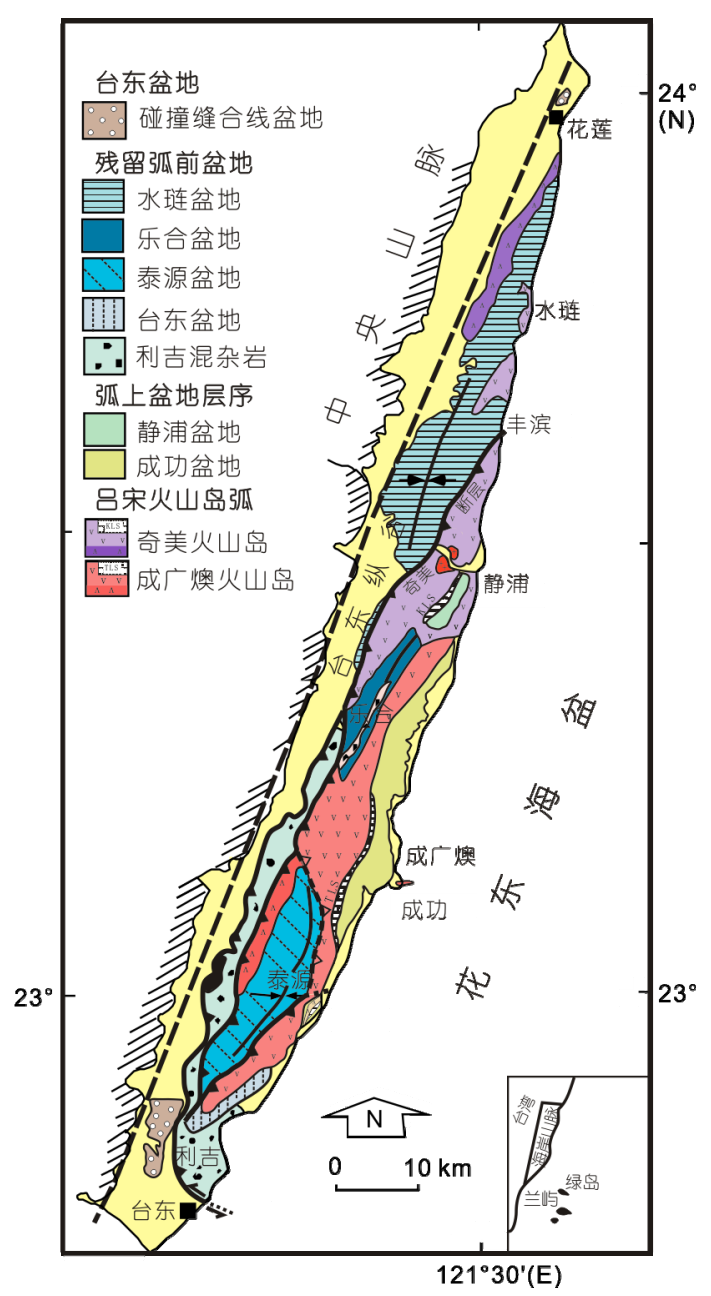

图 13 台湾东部海岸山脉构造地层图(修改自文献[7])

海岸山脉由 4 个残留弧前盆地(自北向南为水牫、乐合、泰源及台东 残留弧前盆地), 2 个独立火山岛(北: 奇美火山岛; 南: 成广煥火山 岛), 附属在火山岛因拉张走滑下陷的两个弧上盆地(北: 静浦盆地; 南: 成功盆地), 及 1 个弧前盆地于弧陆碰撞过程中形成的利吉混杂 岩(弧前碰撞混杂岩 ${ }^{[67,68]}$. 乐合残留弧前盆地及台东残留弧前盆地除 原为弧前盆地的一部分, 其古地理位置也分别位于奇美火山岛-成广 煥火山岛及成广燠火山岛(海岸山脉南段)-绿岛火山岛(尚位于海岸山 脉东南方海域)间闸口. 因斜向弧陆碰撞乐合盆地于 $3.5 \mathrm{Ma}$ 时封闭, 台东盆地于 1 Ma 时封闭

三角洲扇砾石(水琏砾岩，3.6 3.3 Ma)及更新世深海 扇砾石 $(\text { 奇美砾岩 })^{[70]}$, 只能在北方的水牫残留弧前盆 地内沉积, 无法越过位于奇美火山岛(北)及成广燠火 山岛(南)间已变形-抬升的乐合盆地沉积构造坝，将 沉积物往南轮送到乐合盆地及更南方的泰源残留弧 前盆地 ${ }^{[69]}$. 乐合盆地的封闭也导致太平洋深层水团 困难通过奇美火山岛(北)及成广燠火山岛(南)间闸口 进人南海深海盆，因此南海 ODP 1148 站位底栖有孔 


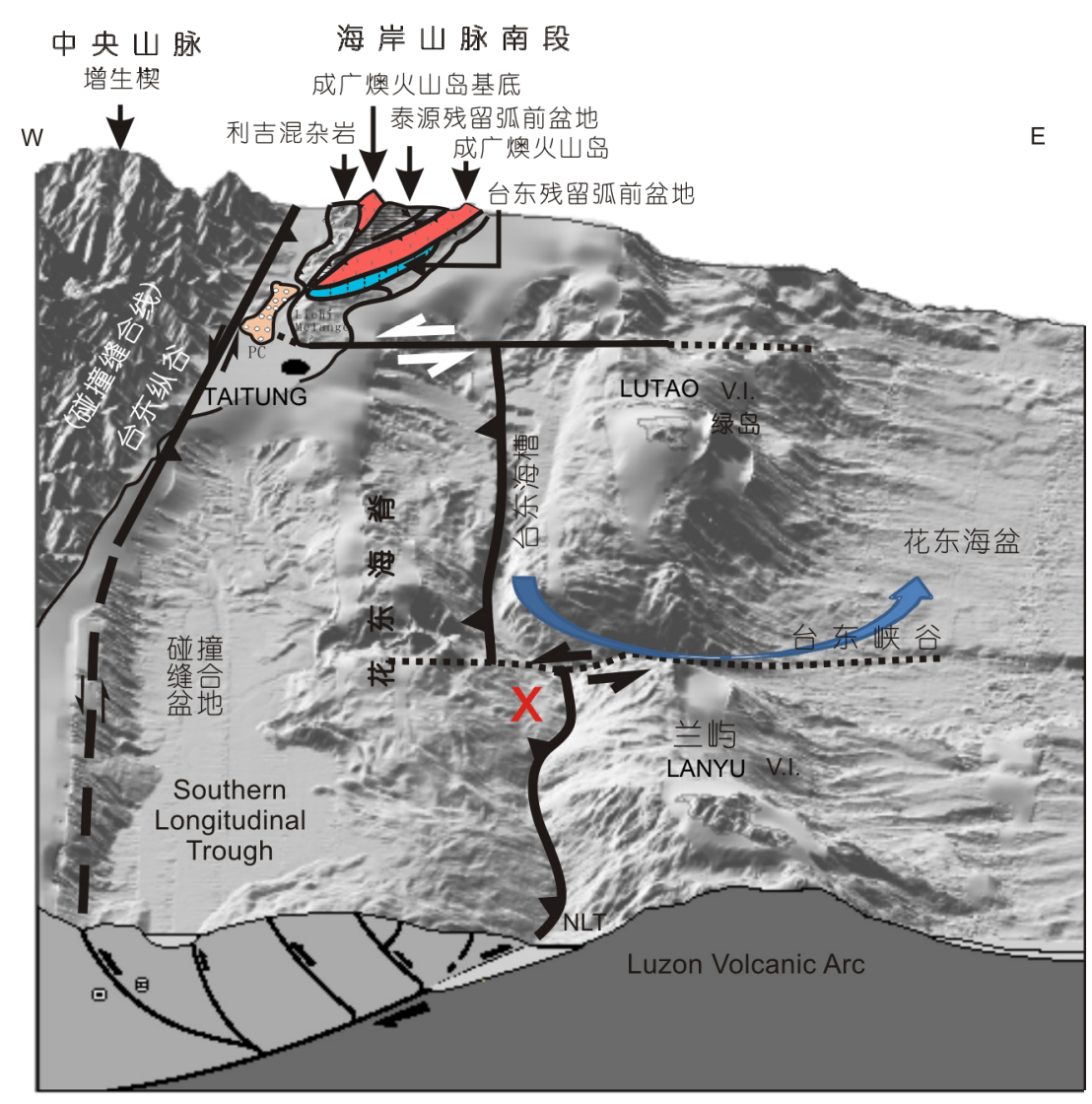

图 14 台湾东南海域初期弧陆碰撞带内(海床立体地形取自文献[71])

北吕宋海槽弧前盆地西侧因背逆冲构造变形为花东海脊 ${ }^{[7,9]}$, 进而将绿岛-兰屿火山岛间闸口沉积物变形及抬升为花东海脊的一部分 $(\mathrm{X}$ 处), 产 生类似沉积构造坝作用. 现代沉积物经由卑南大溪及海下水道向南输送到绿岛西侧台东海槽残留弧前盆地时, 沉积物则因受阻于此沉积构造

坝 $(\mathrm{X}$ 处), 转而沿台东峡谷被向东输送人台湾东侧海域的花东海盆(蓝色箭头). 此沉积构造坝也阻碍西太平洋深层水进入南海中央海盆

虫化石碳同位素值在 3.5 Ma 时明显偏更负值 (图 8). 由于斜向弧陆碰撞, 构造演化向南迁移的特性 ${ }^{[63]}$, 位 于成广燠火山岛与绿岛闸闸口位置的台东盆地于早 更新世( 1 Ma)时封闭. 现在绿岛-兰屿火山岛间闸口 则正在封闭中 $(\text { 图 14 })^{[70]}$.

在最后 $1 \mathrm{Ma}$ 以来, 北吕宋海槽残留弧前盆地及北 吕宋火山岛弧向西仰冲, 并附加到中央山脉增生楔东 侧成为今日海岸山脉. 因此斜向弧陆碰撞导致北吕宋 火山岛链间闸口由北向南在 3.5 , 及 1 发生完全封闭. 在最后 $4 \mathrm{Ma}$ 以来由于兰屿以北火山岛间闸口的半封 闭-完全封闭, 使得西太平洋与南海水团间交换的产 生不稳定性, 最终导致南海 ODP1148 站位底栖有孔虫 碳同位素值在第(III)阶的持续偏负及明显震荡(图 10).

\section{5 结论}

台湾岛造山带新生代地层由古生代(?)-中生代前 张裂基盘, 古近纪同张裂层序及晚渐新世-新近纪后
张裂层序组成，三者间以前张裂不整合面及破裂不 整合面为界. 台湾岛新生代层序原都在南海北部陆 坡以上环境沉积, 因南海海洋岩石圈向东俯冲于菲 律宾海板块之下的板块聚合构造, 这些新生代沉积 物才被变形为台湾造山带. 因此台湾造山带中出露 的新生代层序是了解南海北坡地质的极佳地质窗口, 可以和 ODP 1148 站位所记录的南海深海层序、沉积、 古气候、古海洋学记录相比较, 而得到下列结论:

(1) 台湾中始新世同张裂层序与晚渐新世后张 裂层序间, 存在一个区域性的破裂不整合面, 称为 “埔里运动”, 缺失了晚始新世-早渐新世地层记录 (33 39 Ma). 台湾地区埔里运动破裂不整合面可以和 南海北坡珠江口盆地的南海运动 $\mathrm{T}_{7}$ 不整合面对比.

（2）亚洲大陆边缘基盘上正断层断陷作用产生 南海北坡古新世-始新世的张裂盆地. 随后地壳持续 拉张减薄伴随地幔流上涌导致南海海洋地壳的形成. 因此台湾地区破裂不整合面时间的确定，间接推论 
南海海洋地壳可能在 33 39 Ma 时形成.

（3）台湾海峡及台湾岛造山带层序中并未发现 于渐新世/中新世界面附近的地层缺失和/或沉积崩滑 现象, 表明在南海北坡 ODP 1148 站位(-3294 m 水深) 所记录的渐新世/中新世界面附近的地层缺失和沉积 崩滑现象, 可能只见于南海深海区, 而未见于台湾岛台湾海峡浅海陆棚区域.

(4) 与南海 ODP 1148 深海岩心所记录中中新世以 来的古海洋重组事件比较, 台湾浅海区的记录显示在 沉积和化石组合也发生变化. 在沉积方面, 自中中新 世最暖期, 也是最高海平面时期的上陆坡打鹿叶岩 (16 14.5 Ma)向上变浅(因南极冰盖快速扩张, 全球海 水面下降而逐渐发生海退), 沉积环境改变为陆棚相观 音山砂岩(14.5 13.5 Ma), 再浅化为海滨砂-砂丘-沼泽 环境含煤的南庄层(13.5 10 Ma). 此时也伴随发化石 丰度, 变异度及化石组成内容的改变(称为后打鹿阶 生物间隙). 早-中期中新世存在的台湾地方性底栖有 孔虫化石在 14 13 Ma 间绝灭消失, 然后在 $10.2 \mathrm{Ma}$ 以 后逐渐被现代生活在黑潮流经的陆棚生物组合所取代. 推测这是由于澳大利亚大陆与印度尼西亚火山岛弧间 的俯冲-碰撞(12 8 Ma), 关闭了太平洋-印度洋间的穿 越流水道, 强化了北太平洋西边界流黑潮所引起的古 海洋重组事件. 台湾地区于中/晚中新世界面附近发生 的化石群取代事件, 与南海 ODP 1148 底栖有孔虫氧同
位素地层由第(I)阶改变为第(II)阶时间几乎是同时的.

(5) 产生南海半封闭的机制与南海海洋岩石圈 向东俯冲于菲律宾海板块之下, 产生了台湾岛-吕宋 岛之间的恒春海脊增生楔及北吕宋火山岛弧, 息息 相关. 恒春海脊向北延伸出露为恒春半岛-中央山脉 增生楔, 而北吕宋火山岛弧向西北仰冲形成了今日 台湾东部的海岸山脉。恒春海脊增生楔和北吕宋火 山岛弧对西太平洋与南海水团交换直接地构成了地 形上的阻碍作用，也间接地影响了南海深海盆的底 栖有孔虫碳同位素地球化学性质的改变及古海洋的 变化, 尤其在下列地质时间更为明显：15 8 Ma 时恒 春海脊增生楔的形成和北吕宋火山岛弧持续火山喷 发活动; $6.5 \mathrm{Ma}$ 时恒春海脊增生楔开始出露海平面之 上; $3.5 \mathrm{Ma}$ 时奇美火山岛与成广燠火山岛间闸口乐合 盆地半封闭; $1 \mathrm{Ma}$ 时成广燠火山岛与绿岛间闸口台 东盆地半封闭; $0 \mathrm{Ma}$ 现在绿岛-兰屿间火山岛间闸口 正在封闭中. 北段的弧前盆地及火山岛弧在最后 1 $\mathrm{Ma}$ 向西仰冲形成海岸山脉, 兰屿以北火山岛间闸口 的半封闭-完全封闭. 在这些构造事件发生时, 南海 ODP 1148 站位岩心的底栖有孔虫碳同位素值地层明 显的负偏移, 表明南海古海洋变化与台湾造山带构 造演化间的强烈关联性.

（6）台湾构造事件对南海古海洋变化的关联整 理如表 1:

\section{表 1 台湾新生代构造演化对南海古海洋变化的关联性}

\begin{tabular}{|c|c|}
\hline 构造事件发生地质背景 & 构造事件对西太平洋与南海水团交换影响 \\
\hline 33 39 Ma 南海海洋地壳开始形成 & 古近纪断陷盆地同张裂层序以湖相-辫状河系-沼泽相沉积为主 \\
\hline 33 15 Ma 南海海洋地壳张裂 & 南海面积达到最大, 估计为今日 2 倍大; \\
\hline $15 \mathrm{Ma}$ 南海海洋岩石圈沿马尼拉 & 南海面积因俯冲而开始逐渐削减; 同时南海北部陆坡沉积物被铲刮人恒春海脊增生楔, 增生楔因此 \\
\hline 海沟向东开始俯冲于菲律宾海板 & 逐渐抬升变浅; 北吕宋火山岛弧开始喷发, 火山角砾岩自-5500 $\mathrm{m}$ 花东海盆海床向上堆积, 并出露为 \\
\hline 块之下 & $\begin{array}{l}\text { 火山岛链; } 16 \mathrm{Ma} \text { 以前 ODP } 1148 \text { 早中新世底栖有孔虫碳同位素值与太平洋记录一致, 表明西太平洋- } \\
\text { 南海底层水团交换良好; } 15 \mathrm{Ma} \text { 以后因增生楔及火山岛弧的形成, 太平洋底层水团受阻无法进入南海, } \\
\text { 太平洋深层水团经由火山岛间闸口进入南海, 南海深海盆循环开始受到影响, 底栖有孔虫碳同位素 } \\
\text { 值开始负偏移; 北吕宋火山岛弧主要于 } 15 ~ 6 \mathrm{Ma} \text { 喷发活动, 火山喷发可能提供 } \mathrm{Si}, \mathrm{Fe} \text { 等营养盐, 使南 } \\
\text { 海生产力增加, 导致底栖有孔虫碳同位素值偏负 }\end{array}$ \\
\hline $\begin{array}{l}6.5 \mathrm{Ma} \text { 弧陆碰撞开始发生, 恒春 } \\
\text { 海脊增生楔开始出露 }\end{array}$ & $\begin{array}{l}\text { 恒春海脊增生楔出露为原始中央山脉, 西太平洋-南海水团交换通道至少减少了 } 400 \mathrm{~km} \text { 宽度; ODP } \\
1148 \text { 底栖有孔虫碳同位素值在第(II)阶明显负偏移 }\end{array}$ \\
\hline $3.5 \mathrm{Ma}$ 乐合残留弧前盆地半关闭 & $\begin{array}{l}\text { 奇美火山岛与成广燠火山岛间闸口(乐合盆地)于 } 3.5 \mathrm{Ma} \text { 半关闭; 太平洋深层水进人南海中央海盆 } \\
\text { 减少了通道, 南海底栖有孔虫碳同位素值明显负偏移 }\end{array}$ \\
\hline １ $\mathrm{Ma}$ 台东残留弧前盆地 & 成广燠火山岛与绿岛间闸口(台东盆地) 于 1 $\mathrm{Ma}$ 半关闭; 太平洋深层水进人南海中央海盆又减少 \\
\hline 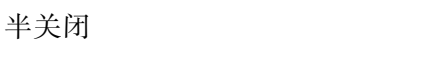 & $\begin{array}{l}\text { 了通道, 南海底栖有孔虫碳同位素值明显负偏移 } \\
\text { 最后 }<1 \mathrm{Ma} \text { 弧前盆地-火山岛弧仰冲形成海岸山脉, 乐合及台东盆地(也是火山岛间闸口) 完全关闭. }\end{array}$ \\
\hline $\begin{array}{l}0 \mathrm{Ma} \text { 现代绿岛-兰屿间残留弧前 } \\
\text { 盆地半关闭 }\end{array}$ & $\begin{array}{l}\text { 现代绿岛-兰屿间闸口正在关闭; 太平洋深层团进人南海中央海盆减少了通道; 今日兰屿与巴丹岛 } \\
\text { 闸口(巴士海峡) 成为西太平洋深层水进人南海中央海盆之主要通道 }\end{array}$ \\
\hline
\end{tabular}


感谢广州海洋地质调查局姚伯初教授和黄永样教授，同济大学汪品先教授、翦知涽教授、田军教授、吴国瑄教 授对南海珠江口盆地层序和南海古海洋研究的讨论.

\section{参考文献}

1 Taylor B, Hayes D E. The tectonic evolutionof the South China Sea. In: Hayes D E, ed. The Tectonic and Geological Evolution of Southeast Asian Seas and Islands, Part I. AGU, 1980, 23: 89-104

2 姚伯初, 曾维军, Hayes D E, 等. 中美合作调研南海地质专报. 武汉：中国地质大学出版社, 1994. 204

3 Taylor B, Hayes D E. Origin and history of the South China Sea Basin. In: Hayes D E, ed. The Tectonic and Geological Evolution of Southeast Asian Seas and Islands, Part II. AGU, 1983, 27: 23-56

4 Tsai Y B. Seismotectonics of Taiwan. Tectonophysics, 1986, 125: 17-37

5 Huang C Y, Shyu C T, Lin S B, et al. Marine geology in the arc-continent collision zone off southeastern Taiwan: Implications for late Neogene evolution of the Coastal Range. Mar Geol, 1992, 107: 183-212

6 Huang C Y, Wu W Y, Chang C P, et al. Tectonic evolution of accretionary prism in the arc-continent collision terrane of Taiwan. Tectonophy, 1997, 281: 31-51

7 Huang C Y, Yuan P B, Lin C W, et al. Geodynamic processes of Taiwan arc-continent collision and comparison with analogs in Timor, Papua New Guinea, Urals and Corsica. Tectonophy, 2000, 325: 1-21

8 Sun S C. The Tertiary basins of offshore Taiwan. Proc. 2nd ASCOPE Conference and Exhibition, Manila, Philippines, 1982. 125-135

9 Reed D L, Lundberg N, Liu C S, et al. Structural relations along the margins of the offshore Taiwan accretionary wedge: Implications for accretion and crustal kinematics. Acta Geol Taiwan, 1992, 30: 105-122

10 Wang P, Li Q. The South China Sea. Paleoceanogr Sediment, 2009, 13: 515

11 Wang P, Prell W L, Blum P. Proceeding of ODP Init. Repts. 184 (CD-ROM). Ocean Drilling Program, Texas A\&M University, College Station, 2000, TX77845-9547

12 Li Q, Wang P, Zhao Q, et al. A 33 Ma lithostratigraphic record of tectonic and paleoceanographic evolution of the South China Sea. Marine Geol, 2006, 230: 217-235

13 Tian J, Shevenell A, Wang P, et al. Reorganization of Pacific Deep Waters linked to middle Miocene Antarctic cryosphere expansion: A perspective from the South China Sea. Paleogeogr Paleoclimatol Paleoecol, 2009, 284: 375-382

14 Zhao Q, Jian Z, Wang P, et al. Neogene oxygen isotopic stratigraphy, ODP Site 1148, northern South China Sea. Sci China-Ser D, 2001, 44: 939-942

15 Zhao Q, Wang P, Cheng X, et al. A record of Miocene carbon excursions in the South China Sea. Sci China-Ser D, 2001, 44: 943-951

16 萧宝宗，胡锦城，林国安，等. 澎湖盆地油气潜能评估. 台湾石油地质, 1991, 26: 215-229

17 原振维. 台湾中西部井下火成岩体之放射性定年. 见: 苗栗, 编. 中国石油公司探采研究所探采研究汇报. 1981, 4: 363-366

18 Huang T C, Chi W R. Calcareous nannofossils of the subsurface Pre-Miocene rocks from the Peikang Basement High and adjacent areas in western Central Taiwan (Part II: Paleocene). Petrol Geol Taiwan, 1979, 16: 95-129

19 黄奇瑜. 由西部麓山带始新世张裂盆地层序的认识检讨雪山山脉的地层. 经济部中央地质调查所特刊, 2009, 22: 47-62

20 Huang C Y, Chi W R, Yan Y, et al. The first record of Eocene sequence in a marine Paleogene rifting basin near Nantou, Western Foothills, central Taiwan. J Asian Earth Sci, 2012

21 Huang C Y, Chi W R, Liew P M, et al. Significance of indigenous Eocene larger foraminifers Discocyclina dispansa in Western Foothills, central Taiwan: A Paleogene marine rifting basin in Chinese continental margin. J Asian Earth Sci, 2012 Ho C S, Tsan S F, Tan L P. Geology and coal deposit of the Chichitashan area, Nantou, Taiwan. Geol Surv Taiwan Bull, 1956, 9: 1-80 Ho C S. Correlation of the Takeng Formation and some related stratigraphic principles. Proc Geo Soc China, 1961, 4: 61-71

24 Huang C Y, Cheng Y M. Oligocene and Miocene planktic foraminiferal biostratigraphy of northern Taiwan. Proc Geol Soc China, 1983 , 26: $21-56$

25 Huang C Y. Oligocene and Miocene stratigraphy of the Kuohsing area, central Taiwan. Acta Geol Taiwan, 1986, 24: 281-318

26 Huang T C. Calcareous nannoplankton, paleoenvironment, age and correlation of the Upper Wulai Froup and the Lower Hsichih Group (Oligocene to Miocene) in northern Taiwan. Proc Geol Soc China, 1978, 21: 128-150

27 Huang T C, Ting J S. Calcareous nannofossils succession from the Oligo-Miocene Peikangchi section and revised stratigraphic correlation between northern and central Taiwan. Proc Geol Soc China, 1979, 22: 105-120

28 Chang L S. Tertiary biostratigraphy of Taiwan. Geol Paleontol SE Asia, 1975, 15: 337-361 
29 Chang L S. A biostratigraphic study of the Oligocene in northern Taiwan based on smaller foraminifera. Proc Geol Soc China, 1962, 5: $47-52$

30 Huang T C. Calcareous nannoplanktons stratigraphy of the Upper Wulai Group (Oligocene) in northern Taiwan. Petrol Geol Taiwan, 1977, 14: $147-179$

31 黄奇瑜. 台湾雪山山脉北段地层微古生物分析和时代对比. 经济部中央地质调查所, 2008, 31

32 黄奇瑜. 台湾雪山山脉北段地层微古生物分析和时代对比(二). 经济部中央地质调查所, 2009, 49

33 Kanno S, Chung C T. Tertiary formations and their molluscan faunas from the Central Rang and foothill areas of northern Taiwan. Contri Geol Paleont SE Asia, 1975, 15: 363-391

34 纪文荣, 刘平妹, 黄奇瑜. 雪山山脉北段北势溪剖面干沟层及四棱砂岩地层学研究. 经济部中央地质调查所, 2010,52

35 Fong C K, Huang T, Shea K S. New occurrence of larger Foraminifera in northern Taiwan and its stratigraphic significance. Spec Publ Cent Geol Surv, 1994, 8: 205-212

36 Matsumaru K. Nummilites junbarensis and Assilina formosensis (late Early to early Middle Eocene) from Taiwan (Formosa). Revue Palébiol, Genève, 2005, 24: 551-561

37 陈勉铭, 游能悌, 朱效祖, 等. 雪山山脉南段武界地区所谓“眉溪砂岩”发现的古第三纪大型有孔虫露头. 经济部中央地质调查所特 刊, 2009, 22: 227-242

38 Yen T P. The Eocene sandstones in the Hsuehshan Range Terrain, northern Taiwan. Proc Geol Soc China, 1973, 16: 97-110

39 Huang T C. A calcareous nannofossils biostratigraphic study of the Assilina-bearing section, Chunkengchi, Nantou. Proc Geol Soc China, 1980, 23: 7-15

40 Blow W H. Late Middle Eocene tp Recent planktonic foraminiferal biostratigraphy. In: Bronnimann P, Renz H H, eds. Proceedings of the First International Conference On Planktonic Microfossils. 1969. 199-421

41 Wade B S, Pearson P N, Berggren W A, et al. Review and revision of Cenozoic tropical planktonic foraminiferal biostratigraphy and calibration to the geomagnetic polarity and astronomical time scale. Earth Sci Rev, 2011, 104: 111-142

42 李锡堤, 王源. 台湾南部横贯公路礼观一带之地层及构造. 地质, 1985, 6: 1-20

43 Chang L S. The Lushanian Stage in the Central Range of Taiwan and its fauna. In: Takayanagi Y, Saito T, eds. Progress In Micropaleontology. New York: Micropaleontology Press, 1976. 27-35

44 Huang T C. Calcareous nannofossils from the Slate Terrane west of Yakou, Southern Cross-Island Highway. Petrol Geol Taiwan, 1980, 17: 59-74.

45 Hashimoto W, Matsumaru K. On the Lepidocyclina-bearing limestone exposed at the Southern Cross-Mountain Highway, Taiwan. Geol Paleont SE Asia, 1975, 16: 103-116

46 Chang L S. Eocene/Miocene hiatus and N Conglomerate in the Central Range of Taiwan. Proc Geol Soc China, 1972, 15: 93-98

47 张丽旭. 台湾之地史. 台湾银行季刊, 1955, 7: 1-7

48 庞雄, 陈长民, 彭大钧, 等. 南海珠江深水扇系统及油气. 北京: 科学出版社, 2007. 360

49 Briais A, Patriat P, Tapponnier P. Update interpretation of magnetic anomalies and seafloor spreading stages in the South China Sea: Implication for the Tertiary tectonics of southeast Asia. J Geophys Res, 1993, 98: 6299-6328

50 Huang C Y. Late Oligocene benthic foraminiferal assemblages in northern Taiwan: The Second International Symposium On Benthic Foraminifera. 1984. 317-323

51 Huang T C. A supplementary note on the calcareous nannofossils, age, and correlation of the Wuchihshan Formation. Petrol Geol Taiwan, 1979, 16: 85-93

52 Huang C Y. Biometric study of Lepidocyclina in the Kungkuan Tuff of northern Taiwan. Acta Geol Taiwan, 1979, 20: 41-51

53 Haq B U, Hardenbol J, Vail P R. Chronology of fluctuating sea level since the Triassic. Science, 1987, 235: 1156-1167

54 Huang, T C. The Oligocene/Miocene boundary in Taiwan. Memoir Geol Soc China, 1979, 3: 103-123

55 Miller K G, Fairbank R G, Mountain G S. Tertiary oxygen isotope synthesis, sea level history, and continental marine erosion. Paleoceanol, 1987, 2: 1-19

56 Woodruff F, Douglas R G. Response of deep-sea benthic foraminifera to Miocene paleoclimatic events, DSDP Site 289. Mar Micropal, 1981, 6: 617-632

57 Huang C Y. Implication of the Post-Lushanian faunal change for the occurrence of Kuroshio Current in the early late Miocene: Foraminiferal evidence from the Chuhuangkeng section, northern Taiwan. Proc Geol Soc China, 1989, 32: 21-45

58 Chang L S. A biostratigraphic study of the Miocene in western Taiwan based on smaller foraminifera (Part II: benthonics). Bull Geol Surv Taiwan, 1960, 12: 67-91

59 Wang P, Zhang J, Qinbao M. Distribution of foraminifera in surface sediments of the East China Sea. In: Wang P, ed. Marine Micropaleontology of China. Berlin: Spring-Verlag, 1985. 34-69 
60 Kennett J P, Keller G, Srinivasan M S. Miocene planktonic foraminiferal biogeography and paleoceanographic development of the IndoPacific region. Geol Soc Amer Mem, 1985, 163: 197-236

61 Qu T, Girton J B, Whitehead J A. Deepwater overflow through Luzon Strait. J Geophys Res, 2006, 111: CO1002, doi: 10.1029/ 2005JC003139

62 Zachos J, Pagani M, Sloan L, et al. Trends, rhythms, and aberrations in global climate 65 Ma to Present. Science, 2001, 292: 686

63 Huang C Y, Yuan P B, Tsao S J. Temporal and spatial records of active arc-continent collision in Taiwan: A synthesis. Geol Soc Am Bull, 2006, 118: 274-288

64 Yang T Y, Liu T K, Chen C H. Thermal event records of the Chimei igneous complex: Constraint on the ages of magma activities and the structural implication based on fission track dating. Acta Geol Taiwan, 1988, 26: 237-246

65 Chang L S. A biostratigraphic study of the Tertiary in the Hengchun Peninsula, Taiwan, based on smaller foraminifera (III: Southern Part). Proc Geol Soc China, 1966, 9: 55-63

66 Huang C Y, Yuan P B, Song S R, et al, Tectonics of short-lived intra-arc basins in the arccontinent collision terrane of the Coastal Range, eastern Taiwan. Tectonics, 1995, 14: 19-38

67 Chang C P, Angelier J, Huang C Y, et al. Structural evolution and significance of a melange in a collision belt: The Lichi Melange and the Taiwan arc-continent collision. Geol Mag, 2001, 138: 633-651

68 Huang C Y, Jien C W, Chang C P, et al. The Lichi Melange: A tectonic collision complex originated form sheared forearc in Coastal Range, eastern Taiwan. Geol Soc Am, Spec Pap, 2008, 436: 127-154

69 林彦均. 台湾东部海岸山脉中段乐合残留弧前盆地之构造演化以及利吉混杂岩体成因探讨: 微体古生物与黏土矿物证据. 硕士学 位论文. 台南: 成功大学地球科学系, 2010.1-50

70 Huang C Y, Zhao Q, Jian Z. Fluctuations of bottom water paleoceanography of South China Sea linked to tectonic evolution of accretionary prism-Luzon volcanic arc in Taiwan region. AGU Fall Meeting, EOS, OS54A-03

71 Malavieille J, Lallemand S E, Dominguez S, et al. Arc-continent collision in Taiwan: New marine observations and tectonic evolution. Geol Soc Am, Spec Pap, 2002, 358: 187-211

\section{补充材料}

图 S1 台湾北部雪山山脉 5 个研究剖面标本采样位置图

图 S2 四棱砂岩野外产状

图 S3 北部横贯公路剖面(图 S1(e))四棱砂岩产底栖有孔虫化石

本文的以上补充材料见网络版 csb.scichina.com. 补充材料为作者提供的原始数据, 作者对其学术质量和内容负责. 